九州大学学術情報リポジトリ

Kyushu University Institutional Repository

Taxonomic Study of the Genus Ceutorhynchoides Colonnelli, 1979 from Japan, with Establishment of an Allied New Genus (Coleoptera: Curculionidae: Ceutorhynchinae)

Yoshitake, Hiraku

Graduate School of Bioresource and Bioenvironmental Sciences, Kyushu University

Colonnelli, Enzo

https://doi.org/10.5109/2705

出版情報: ESAKIA. 45，pp.117-153，2005-03-31. Entomological Laboratory，Faculty of Agriculture, Kyushu University

バージョン：

権利関係 : 
ESAKIA, (45): 117-153. March 31, 2005

\title{
Taxonomic Study of the Genus Ceutorhynchoides Colonnelli, 1979 from Japan, with Establishment of an Allied New Genus (Colleoptera: Curculionidae: Ceutorhynchinae)*
}

\author{
Hiraku YoSHITAKE \\ Entomological Laboratory, Graduate School of Bioresource and Bioenvironmental Sciences, \\ Kyushu University, Fukuoka, 812-8581 Japan \\ and \\ Enzo ColonNelli \\ Via delle Giunchiglie 56, 00176 Roma, Italy
}

\begin{abstract}
The genus Ceutorhynchoides Colonnelli (Ceutorhynchini, Ceutorhynchinae) is recorded for the first time from Japan, with descriptions of two new species: C. squamatus sp. nov. (Ryukyus) and C. styracis sp. nov. (Honshu, Shikoku, and Kyushu). In addition, Hainokisaruzo gen. nov., which is related to Ceutorhynchoides, is established for three Japanese species: $H$. japonicus sp. nov. (type species; Honshu and Kyushu), H. nipponensis (Hustache), comb. nov. (Honshu and Kyushu), and H. infuscatus sp. nov. (Honshu, Shikoku, Kyushu, and Ryukyus). Based on morphological reason, Ceutorhynchoides bengalensis Colonnelli, C. notatus Colonnelli, C. topali Colonnelli, C. subcostulatus (Hustache), and C. sinensis Korotyaev from the Oriental Region are transferred to Hainokisaruzo (comb. nov.). A key to species, habitus photographs, and illustrations and SEM photographs of important characters are provided for the Japanese species of both genera. The following host association records are also given in this paper: Ceutorhynchoides styracis with Styrax japonica Siebold et Zuccarini (Styracaceae), Hainokisaruzo japonicus with Symplocos glauca (Thunberg) Koidzumi (Symplocaceae), and H. nipponensis with Symplocos chinensis (Loureiro) Druce (Symplocaceae).
\end{abstract}

Key words: Taxonomy, Coleoptera, Curculionidae, Ceutorhynchinae, Ceutorhynchini, new species, host plant, Symplocos, Styrax.

\footnotetext{
* Contribution from the Entomological Laboratory, Faculty of Agriculture, Kyushu University,
} Fukuoka (Ser. 6, No. 13) 


\section{Introduction}

The genus Ceutorhynchoides Colonnelli, 1979 belonging to the tribe Ceutorhynchini Gistel, 1848, subfamily Ceutorhynchinae Gistel, 1848 is characterized mainly by the subconical prothorax with a pair of discal prominences, no lateral tubercles, and crenulate basal margin (Colonnelli, 2004).

This genus was first established by Colonnelli (1979) for three species: Ceutorhynchoides badius Colonnelli, 1979 from Bhutan, C. elongatus Colonnelli, 1979 also from Bhutan, and C. subcostulatus (Hustache, 1920) from South India. After that, Colonnelli (1984) and Korotyaev $(1981,1989)$ added three species from North India (Bengal and Assam) and two species from South China (Yunnan), respectively. Recently, Colonnelli (2004) transferred Lytodactylus testaceus Motschulsky, 1866 from Sri Lanka to this genus and Korotyaev \& Hong (2004) described Ceutorhynchoides koreanus from the Korean Peninsula. Thus, ten species of Ceutorhynchoides are known to occur in Indo-Chinese region at the moment. Although no species have hitherto been recorded from Japan, the occurrence of Ceutorhynchoides was strongly expected from the distribution pattern of this genus.

Through our on-going study of Oriental Ceutorhynchinae, we found four undescribed species from Japan, which should be placed in Ceutorhynchoides. Morphologically, Japanese species, together with other congeners, could be divided into two distinct groups. In light of the recent generic classification of the subfamily (e.g., Korotyaev, 1981; Egorov et al., 1996; Colonnelli, 2004), morphological and ecological differences between the two groups indicate that they must be classified into two distinct genera.

In this paper, therefore, we redescribe the genus Ceutorhynchoides and establish an allied new genus with detailed descriptions of four new species from Japan. Biological notes on four species are also provided, in addition to a key to Japanese species of both genera. This study is the first part of our comprehensive revision of Ceutorhynchoides and its relatives from the East Palearctic and Oriental Regions.

\section{Materials and Methods}

Besides our private collections (EC: E. Colonnelli Collection, Rome; HY: H. Yoshitake Collection, Fukuoka), this study was based on specimens preserved in the following institutions: Entomological Laboratory, College of Agriculture, Ehime University, Matsuyama (ELEU); Entomological Laboratory, Faculty of Agriculture, Kyushu University, Fukuoka (ELKU) ; Hokkaido University Museum, Sapporo (HUM); Wakayama Prefecture Museum of Natural History, Kainan (WPMNH). Methods used here for descriptions are the same as those explained in Yoshitake \& Yamauchi (2002). All holotypes are deposited in ELKU and paratypes are in EC, ELEU, ELKU, HUM, HY, and WPMNH. The scientific names of host 
plants were quoted from Satake et al. $(1989 \mathrm{a}, \mathrm{b})$.

\section{Taxonomy}

\section{Ceutorhynchoides Colomnelli, 1979}

Ceutorhynchoides Colonnelli, 1979: 144 (type species: Ceutorhynchoides badius Colonnelli, 1979). - Korotyaev, 1981: 130. - Colonnelli, 1984: 201. - Korotyaev, 1989: 155. Egorov et al., 1996: 463 (in key). - Colonnelli, 2004, 36. - Korotyaev \& Hong, 2004, 160.

Diagnosis. Ceutorhynchoides Colonnelli is characterized by a combination of the following features: 1) apex of antennal scape (Figs. 18, 20) rounded and bearing 2-4 very long hairs on ventral surface; 2) antennal scrobes (Figs. 12, 13, 15, 16) separated from each other in entire width; 3) pronotum (Figs. 21, 24) with a pair of tubercles in middle, lacking a row of particular scales along basal margin; 4) basal margin of pronotum serrate; 5) apical margin of pronotum evidently raised; 6) basal margin of each elytron fringed with a row of long hairs; 7) elytra with three bands of squamate tubercles; 8) rostral groove wanting or diminished to shallow median concavities on meso- and metasterna; 9) ventrite V (Fig. 36) wide in both sexes.

Redescription. Body (Figs. 1-4) small, 2.08-3.30 mm in length, more or less plump, generally clothed with dense scales; each scale (Figs. 23, 26) wide in varying degrees and strongly dilated toward apex. Reddish brown to dark brown in general appearance; basal margins of pronotum and elytra black.

Head (Figs. 11, 14) with a short median carina on vertex; forehead shallowly depressed, hardly raised along inner margin of each eye. Eyes weakly prominent from outline of head. Rostrum slender, much longer than prothorax in both sexes, clothed with scales near base; scales becoming minute and indistinct apically; apical part beyond antennal insertions nearly naked; dorsum shallowly punctured; punctures becoming minute and sparse apically; antennal scrobes (Figs. 12, 13, 15, 16) situated on lateral surface of rostrum and separated to one another in entire length. Antennae slender; scape (Figs. 18, 20) clavate, rounded at apex, lacking projection; apex furnished with 3-4 very long hairs on ventral surface; funicle 7segmented. Pronotum (Figs. 21, 24) emarginate at middle of apical margin, with a median sulcus along midline, bearing tubercle on each side of sulcus; tubercles furnished with darkcolored scales; basal margin serrate, weakly bisinuate, flat or weekly edged on to either side of middle, lacking row of special scales; sides covered only with ordinary scales, devoid of oval ones; apical margin evidently upraised in profile. Scutellum linear to drop-shaped, shining. Elytra (Figs. 22-26) dorsally moderately convex, with 3 transverse bands of tubercles on 


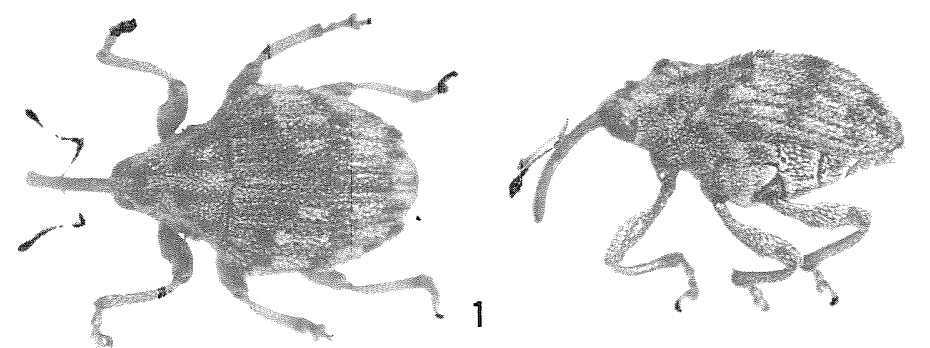

2
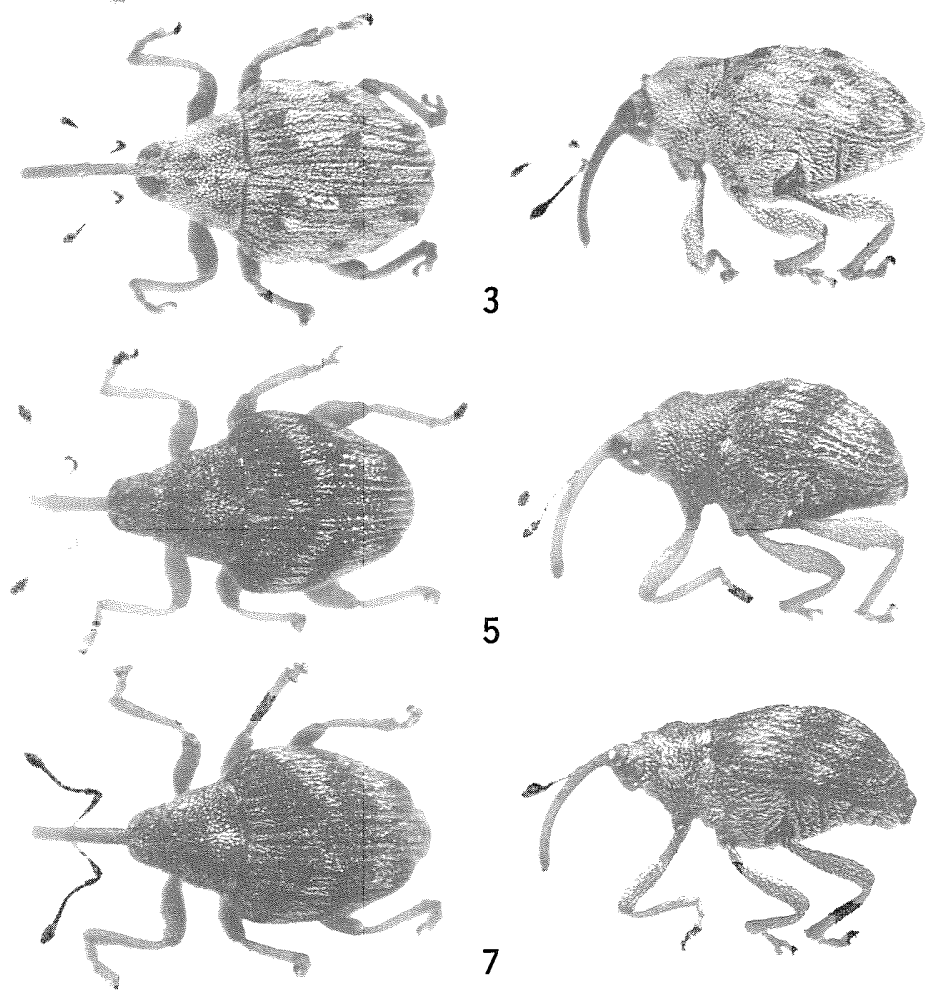

\section{7}

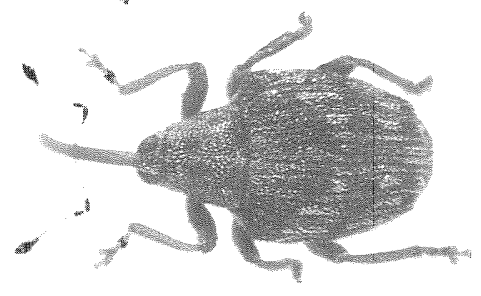

7

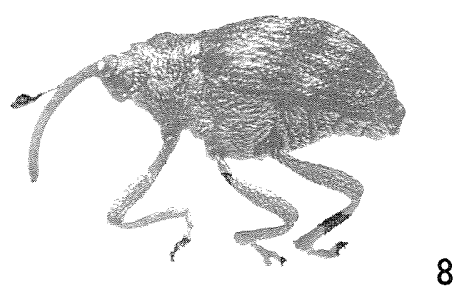

9

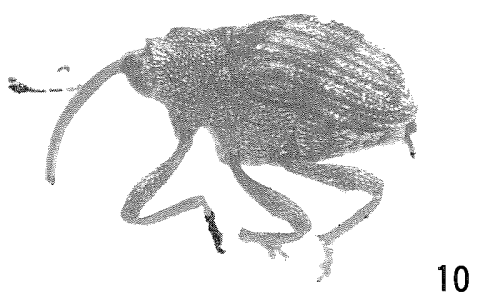

Figs. 1-10. Habitus of Ceutorhynchoides and Hainokisaruzo spp. - 1, 2, Ceutorhynchoides squamatus sp. nov., male; 3, 4, C. styracis sp. nov., male; 5, 6, Hainokisaruzo japonicus sp. nov., male; 7, 8, H. nipponensis (Hustache), male; $9,10, H$. infuscatus sp. nov., male; $1,3,5,7,9$, dorsal view; $2,4,6,8$, 10 , lateral view. 
odd numbered intervals in subbasal, median, and subapical parts; each tubercle furnished with dark-colored scales; basal margin of each elytron fringed with a row of very long hairs, which are concealed by basal margin of pronotum when reposed; intervals much wider than striae, and smooth, lacking granules, strongly shining; striae (Figs. 23, 26) well-marked, with a row of small stout scales on interstices between punctures, shining, with round punctation; each puncture separated by distance 2.00-4.00 times as long as its diameter; humeri well-developed. Femora clavate in varying degrees, each armed with a small tooth; tooth concealed by lightcolored scales, rarely obliterated on fore legs; tibiae clothed with fine hairs in apical part; corbels (Figs. 27-32) fringed with dark-colored setae; claws (Figs. 33, 34) appendiculate in varying degrees. Prosternum with a deep rostral groove before coxae; groove limited laterally by keels; mesosternum and anterior part of metasternum flat or shallowly depressed in middle for reception of rostrum. Tergite VII with a pair of minute plectral tubercles. Ventrites III and IV subequal in length. Male sternite IX well-sclerotized.

Distribution. Bhutan, India, Sri Lanka, China, Korea, Japan.

\section{Ceutorhynchoides squamatus sp. nov.}

Diagnosis. Ceutorhynchoides squamatus sp. nov. appears to be close to C. styracis sp. nov. in having the similar general appearance. However, this species differs from C. styracis by the longer and more erect scales on prothorax and elytra (Figs. 22, 23), the slender antennal funicle that is slightly longer than scape (Fig. 17), the stouter hind femora, the slenderer fore tibiae with evident outer dilation (Fig. 27), and the slenderer tarsal segment V (Fig. 33).

Description. Male. Length of body: 2.08-2.43 mm (mean $2.23 \mathrm{~mm}$ ). Length of rostrum: $1.00-1.13 \mathrm{~mm}$ (1.05). Maximum width of pronotum: $0.93-1.08 \mathrm{~mm}$ (0.99). Length of pronotum: $0.68-0.80 \mathrm{~mm}(0.72)$. Maximum width of elytra: $1.38-1.60 \mathrm{~mm}$ (1.48). Length of elytra: $1.45-1.70 \mathrm{~mm}$ (1.59). $\mathrm{N}=8$, for all measurements. Habitus as shown in Figs. 1, 2.

Reddish brown in general appearance; apical half of rostrum, antennal scape, and legs paler; antennae except scape and apex of each tibia infuscate; ventral surface slightly darker.

Body surface generally covered with ochreous powder in life. Vestiture predominantly light ash brown. Prothorax with dark patches composed of blackish scales; patches on anterior margin, center, and sides formed by bundles of suberect to erect very long scales (Fig. 21), mixing with light-colored scales; median pair often connected with basal two pairs. Elytra with 3 black and 3 white transverse scaly bands; black bands being on subbasal, median, and subapical parts; 3 white bands being on ante- and postmedian and apical parts; each band interrupted on even-numbered intervals; black bands composed of bundles of long and erect scales (Figs. 22, 23); white bands composed of suberect to erect scales; each interval (Fig. 23) with 1-4 rows of scales; interval I with 1-3 rows of blackish scales from middle to apical $1 / 4$, connecting median band with subapical one. Legs clothed with wide-claviform scales, 


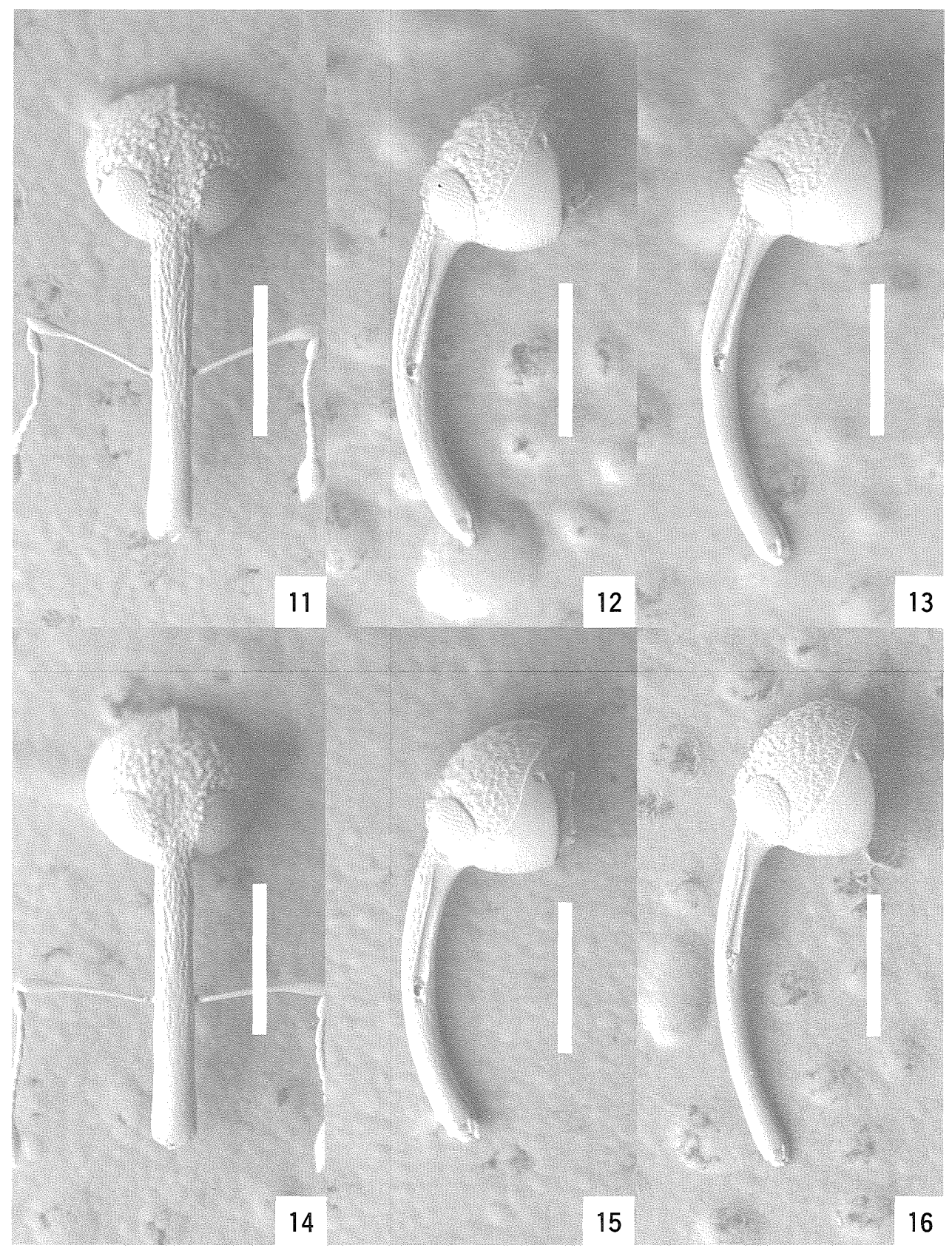

Figs. 11-16. Heads of Ceutorhynchoides spp. -11-13, C. squamatus sp. nov.; 1416, C. styracis sp. nov.; 11, 14, dorsal view, male; 12,15 , lateral view, male; 13, 16, lateral view, female. Scale: $0.50 \mathrm{~mm}$. 
mingled with narrow ones; mid coxae with lanceolate to acicular scales; hind coxae sparsely with minute elliptic scales; trochanter with lanceolate scales; femora with lanceolate to acicular white scales in basal part and with small patches of blackish scales in apical part, each bearing tuft of lanceolate white scales concealing tooth; tibiae clothed with brownish hairs in apical part. Lateral pieces of meso- and metasterna covered with scales in similar shape and color to those on elytra; mesepimera with blackish scales in center. Prosternal canal and meso- and metasterna densely covered with lanceolate to linear-lanceolate white scales, mingled with brownish ones. Venter (Figs. 35, 36) clothed with elliptic to lanceolate white scales; ventrite $\mathrm{V}$ with a pair of scaly tufts along posterior margin, mixing with slender erect hairs. Pygidium (Figs. 37, 38) with clavate scales, mingled with lanceolate and linear ones; each scale dull white to brownish; median sulcus sparsely covered with scales.

Head (Fig. 11) coarsely and reticulately punctured; forehead wide, 1.07 times as wide as rostrum. Rostrum (Figs. 11, 12) 1.41-1.48 times as long as prothorax, rather strongly curved in apical $1 / 3$; dorsum moderately punctured; punctures indistinct in apical $1 / 3$; sides slightly dilated from constricted base, faintly narrowed to antennal insertion, then slightly broadened toward apex, and as wide at apex as forehead. Antennae inserted at middle of rostrum (Fig. 12); scape (Fig. 18) short, 0.75 times as long as funicle, 8.24 times as long as wide, with 2 long hairs on dorsal surface in expanded apical part; funicle (Fig. 17) relatively slender, with segment I 2.40 times as long as wide, 0.91 times as long as II, II 4.40 times as long as wide, III 3.00 times as long as wide, 0.68 times as long as II, IV 2.62 times as long as wide, 0.87 times as long as III, 1.24 times as long as V, V 1.73 times as long as wide, 1.06 times as long as VI, VI 1.64 times as long as wide, 0.82 times as long as VII, VII 1.69 times as long as wide; club rounded-rhomboidal, not constricted near base.

Prothorax (Fig. 21) subtrapezoidal, 1.32-1.41 times as wide as long, 0.44-0.47 times as long as and 0.65-0.69 times as wide as elytra, widest at base, subparallel-sided in basal half, then acutely and straightly convergent toward subapical constriction; dorsum finely and closely punctured, narrowly, strongly, and abruptly prominent, with a rather deep median sulcus.

Elytra (Fig. 22) 1.05-1.10 times as long as wide, 2.13-2.25 times as long as and 1.45-1.54 times as wide as prothorax, widest just behind humeri, subparallel-sided in basal half, moderately narrowed to apical $3 / 4$, then straightly convergent toward subapical calli; intervals (Fig. 23) wide, smooth, lacking granules; prominences rather weak.

Fore femora 3.87 times as long as wide, 1.23 times as long as and 2.50 times as wide as fore tibiae. Mid femora 3.53 times as long as wide, 1.40 times as long as and 2.43 times as wide as mid tibiae. Hind femora 3.69 times as long as wide, 1.28 times as long as and 2.29 times as wide as hind tibiae. Fore tibiae (Fig. 27) 7.83 time as long as wide, simple at apex, not mucronate; corbels relatively long, evidently dilated outward. Mid tibiae (Fig. 28) 6.14 times as long as wide, moderately mucronate at apex; corbels relatively long, slightly dilated 


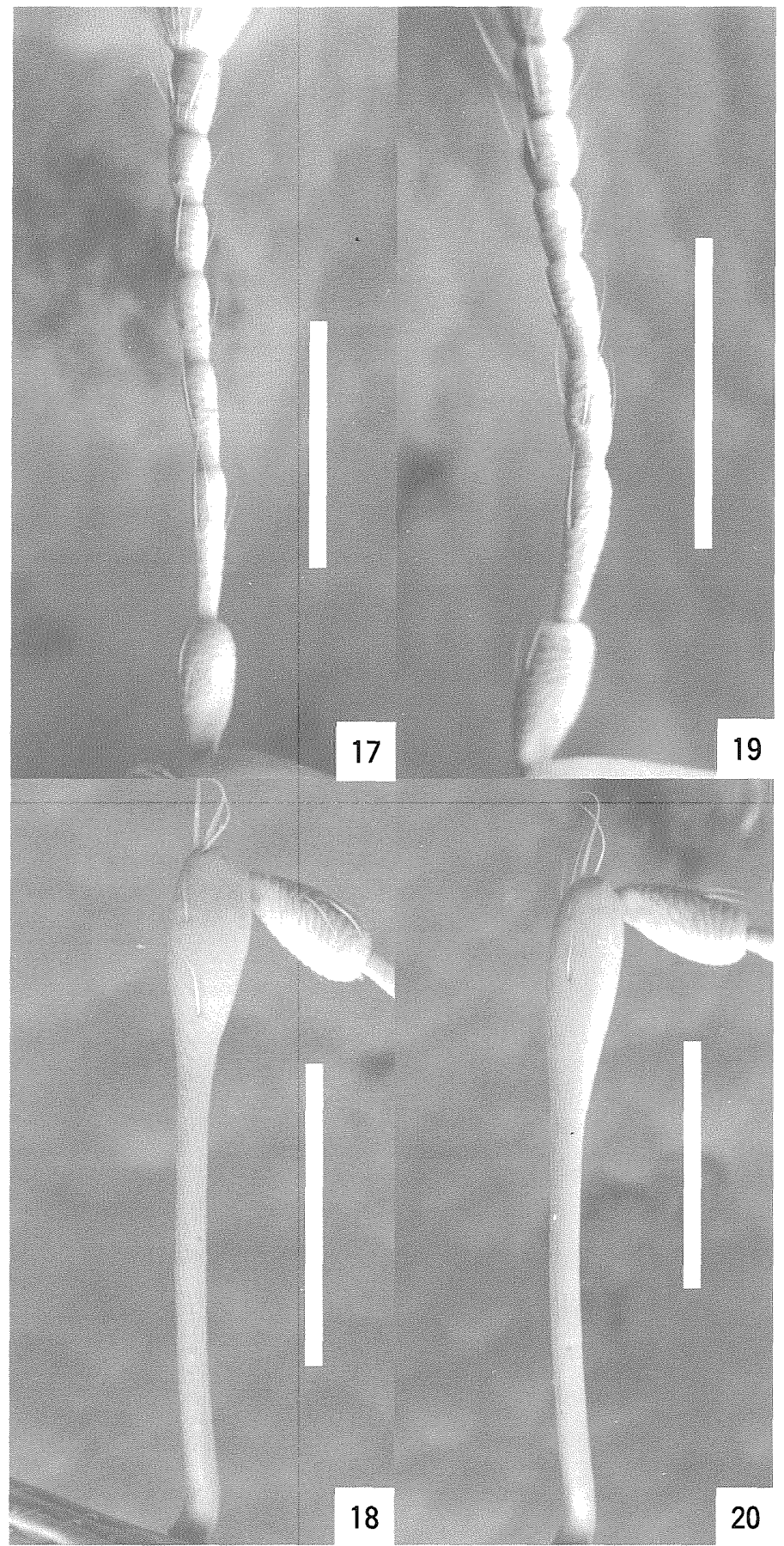

Figs. 17-20. Antennae of Ceutorhynchoides spp. - 17, 18, C. squamatus sp. nov.; 19,20, C. styracis sp. nov.; 17, 19, funicles; 18, 20, scapes. Scale: $0.20 \mathrm{~mm}$. 
outward. Hind tibiae (Fig. 29) 6.57 times as long as wide, with apices as in mid legs. Tarsomere V (Fig. 33) relatively slender.

Venter as in Figs 35, 36; ventrite I coarsely and closely punctured, widely and shallowly concave on disc; punctures smaller in concavity; ventrite II somewhat short, 0.39 times as long as I, 1.90 times as long as III, coarsely and closely punctured, conjointly concave with I; ventrite $\mathrm{V}$ considerably wide, 5.17 times as wide as long, slightly shorter than III and IV taken together, rather deeply concave on disc; posterior margin with a shallow median incision.

Pygidium (Fig. 37) transverse-pentagonal, 2.03 times as wide as long, with a deep longitudinal concavity in middle; punctation indistinct due to dense scales; upper flange evenly arched. Sternite IX (Fig. 42) slightly wider than long; spiculum gastrale much shorter than aedeagus, bent rightward. Tegmen (Fig. 41) with apodeme nearly half as long as tegminal ring, thin, subpallarel-sided. Aedeagal body (Figs. 39, 40) slender, subparallel-sided in basal $1 / 3$, gradually narrowed toward apex, broadly rounded at apex, less-sclerotized basally, and thick, bisinuate, and broadly rounded at apex in profile; apodeme evidently shorter than body. Endophallus (Fig. 39) with a small sclerite in middle, sparsely with minute acicular spicules in apical half.

Female. Length of body: 2.25-2.40 mm (mean $2.32 \mathrm{~mm}$ ). Length of rostrum: 1.13-1.20 $\mathrm{mm}$ (1.16). Maximum width of pronotum: $0.98-1.10 \mathrm{~mm}$ (1.04). Length of pronotum: $0.73-$ $0.80 \mathrm{~mm}(0.75)$. Maximum width of elytra: $1.50-1.63 \mathrm{~mm}$ (1.57). Length of elytra: 1.60 $1.73 \mathrm{~mm}$ (1.66). $\mathrm{N}=5$, for all measurements.

Rostrum (Fig. 13) much slenderer, 1.50-1.58 times as long as prothorax. Antennae inserted just behind middle of rostrum (Fig. 13). Prothorax 1.34-1.44 times as wide as long. Elytra 1.04-1.07 times as long as wide. All tibiae simple at apex, not mucronate. Ventrites I and II shallowly concave and finely sparsely punctured on disc; ventrite V 4.50 times as wide as long. Pygidium (Fig. 38) smaller and slightly narrower, 1.97 times as wide as long, evenly depressed, covered with clavate scales, shining; each side of upper flange straight. Ovipositor (Fig. 44) with coxites stout, long, nearly 3.0 times as long as styli; styli apically inserted, moderate in length, nearly twice as long as broad. Sternite VIII (Fig. 43) furnished with slender setae at apex; arms slender, nearly half as long as apodemes, 1.50 times as long as coxite and stylus combined, narrowly separated; apodemes moderate in length, very weakly divergent near apex. Spermatheca (Fig. 45) with cornu long, attenuate; collum narrowly obliquely convex downward; ramus indistinct, not reaching level of ductal insertion, with outline almost uniformly continuous with body; insertions of duct and gland close to each other. Otherwise practically as in male.

Type material. Holotype male (Type No. 3179, ELKU), Nakamagawarindou, Iriomotejima I., Ryukyus, Japan, 27. v. 1990, H. Kojima. Paratypes (EC, ELKU, HY, WPMNH). JAPAN: RYUKYUS. 2 males and 2 females, same data as the holotype. 1 male, Ohara-Mihara, Iriomotejima I., 19. iv. 1993, H. Kojima. 1 female, Ohtomirindou, Iriomotejima I., 12. iii. 


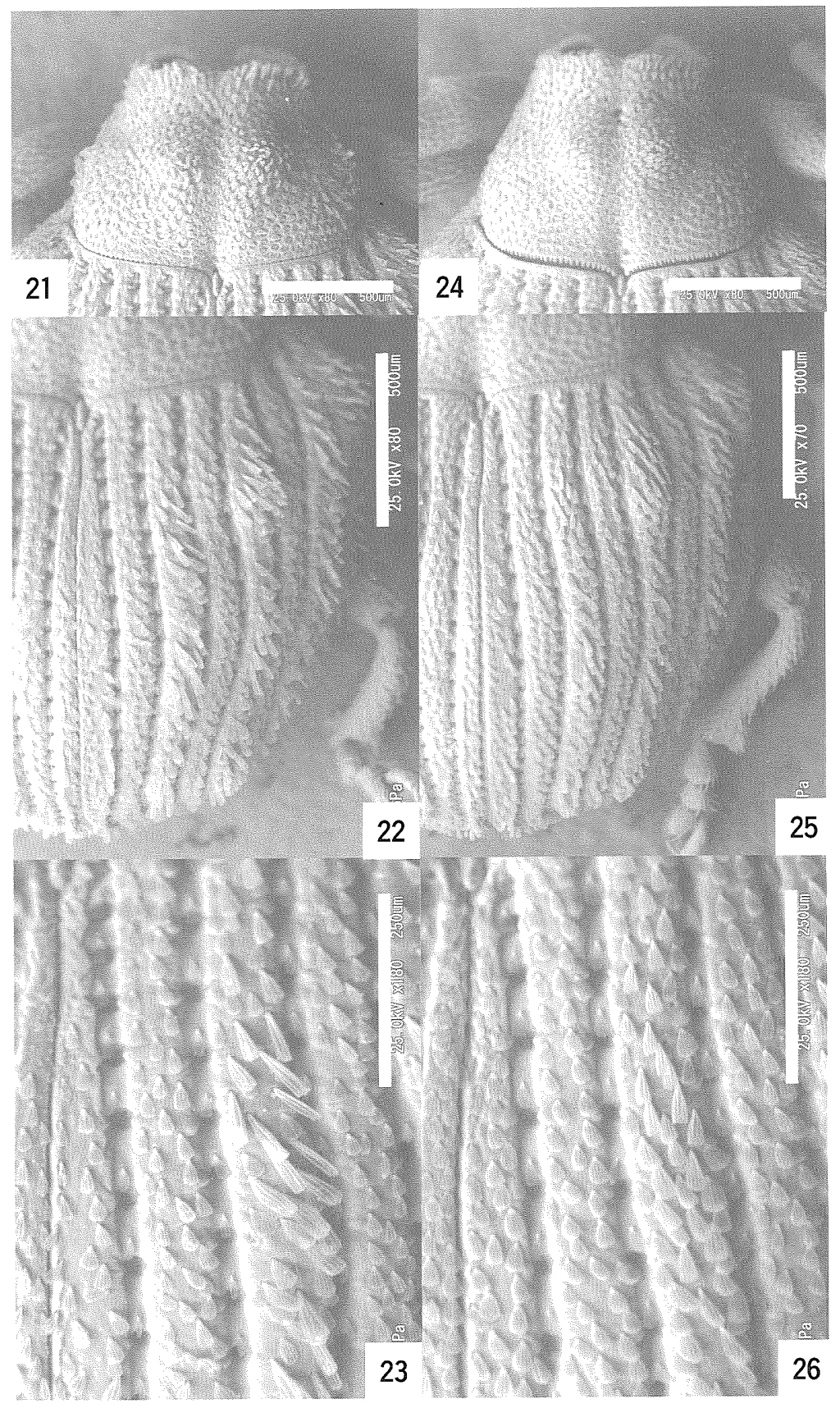

Figs. 21-26. Ceutorhynchoides spp. - 21-23, C. squamatus sp. nov.; 24-26, C. styracis sp. nov.; 21,24 , pronotum; 22,25 , right elytron; 23,26 , ditto, enlarged. Scale: $0.50 \mathrm{~mm}$ for 21, 22, 24, 25; $0.25 \mathrm{~mm}$ for 23,26 . 
1993, Y. Okushima. 1 male, Airagawa, Iriomotejima I., 15. iii. 1998, N. Takahashi. 1 male, Itajikigawa, Iriomotejima I., 8. vii. 1963, Y. Miyatake. 2 males and 2 females, Komi, Iriomotejima I., 2. iii. 1998, I. Matoba. Mt. Omotodake, Ishigakijima I.: 1 female, 16. vii. 1976, S. Kimoto; 2 males, 20-28. iv. 1990, T. Hanatani; 1 male, 19. iv. 1992, H. Kojima. 1 female, Banna, Ishigakijima I., 20. iii. 1990, H. Kojima.

Distribution. Japan (Ryukyus: Iriomotejima I., Ishigakijima I.).

Etymology. This species is named after the densely squamate body.

Comments. Ceutorhynchoides squamatus, together C. styracis from Japan and C. koreanus Korotyaev \& Hong, 2004, constitutes a distinct species group within the genus. They share the following characteristics.

1) Body stouter (Figs. 1, 3). 2) Dark scaly patches of prothorax and elytra welldeveloped and more evident at least on tubercles (Figs. 22, 25), due to concentration of more or less slender and erect scales (Figs. 23, 26). 3) Head clothed with dark scales in the middle; forehead moderately covered with scales, fringed with erect ones along internal margin of each eye. 4) Rostrum (Figs. 12, 13, 15, 16) shorter, 1.37-1.48 times (in male) or 1.48-1.62 times (in female) as long as prothorax, clothed with clavate scales near base. 5) Prothorax (Figs. 21, 24) fundamentally with eight patches of dark narrow scales in addition to two median patches on tubercles: two of eight patches on anterior margin, two in the middle of each side, and four in the middle of basal margin; basal two pairs often indefinite; lateral pair clearly separated from others. 6) Legs stouter; tarsal claws (Figs. 33, 34) narrowly separated by a pair of slender spiniform teeth. 7) Metendosternite with hemiductus moderate in length. 8) Mesosternum and anterior part of metasternum shallowly depressed in the middle for reception of rostrum. 9) Venter (Figs. 35, 36) devoid of minute punctation; ventrite V considerably wide in both sexes, with oblong-ovate concavity on disc and densely covered with upraised scales at sides of concavity in female. 10) Male pygidium (Fig. 37) with a deep longitudinal furrow in the middle. 11) Male aedeagal body (Figs. 39, 40, 46, 47) broadly rounded at apex in profile. 12) Female ventrite $V$ with a longitudinal concavity on disc, bearing a pair of scaly tufts at sides of the concavity.

Our preliminary study suggests that there are at least four undescribed species that should be placed within this species group in Nepal, Laos, and South China. It is noteworthy that one of them from South China may be closely related to C. squamatus, though we suggested the affinity between $C$. squamatus and $C$. styracis in the diagnosis.

\section{Ceutorhynchoides styracis sp. nov.}

Diagnosis. Ceutorhynchoides styracis sp. nov. shows close resemblance to C. koreanus Korotyaev \& Hong in general appearance. However, C. styracis differs from C. koreanus in the antennal funicular segment IV much longer than III, the narrow scutellum, and the male genitalia 


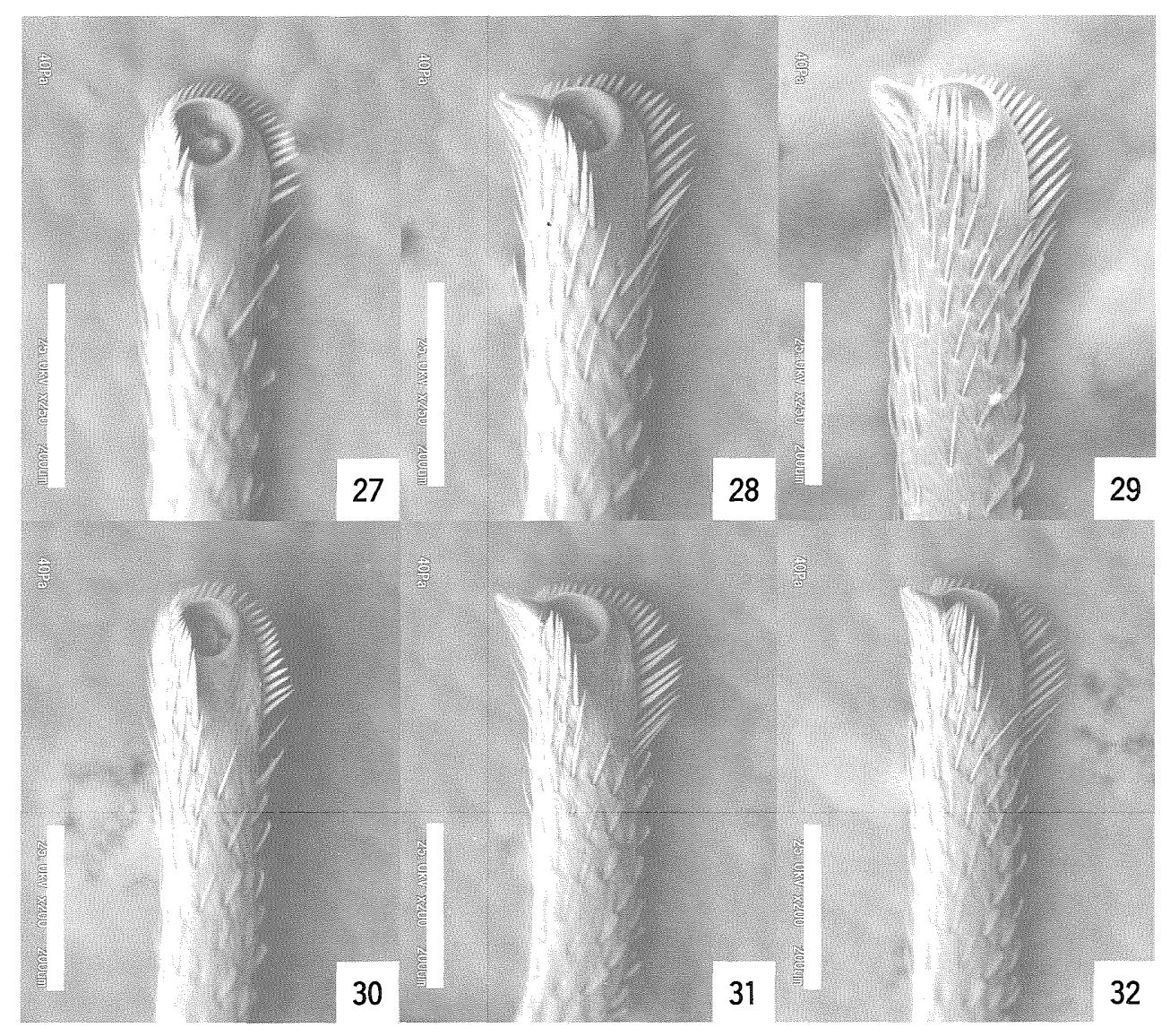

Figs. 27-32. Male tibiae of Ceutorhynchoides spp. -27-29, C. squamatus sp. nov.; 30-32, C. styracis sp. nov.; 27, 30, fore tibiae; 28, 31, mid tibiae; 29, 32, hind tibiae. Scale: $0.25 \mathrm{~mm}$ for 27-29: $0.20 \mathrm{~mm}$ for 30-32.

with wider aedeagal body and a characteristic endophallic sclerite. This species is also similar to C. squamatus, but can be readily discriminated from it by the shorter and more recumbent scales on prothorax and elytra (Figs. 24, 25, 26), the robust antennal funicle (Fig. 19), which is shorter than scape, and the legs with the slenderer hind femora, shorter fore tibiae lacking evident outer dilation (Fig. 30) and robust tarsal segment V (Fig. 34).

Description. Male. Length of body: 2.00-2.33 mm (mean $2.18 \mathrm{~mm}$ ). Length of rostrum: 0.93-1.08 mm (1.01). Maximum width of pronotum: 0.90-1.03 mm (0.97). Length of pronotum: $0.68-0.75 \mathrm{~mm}(0.72)$. Maximum width of elytra: $1.35-1.58 \mathrm{~mm}$ (1.46). Length of elytra: $1.38-1.65 \mathrm{~mm}(1.53) . \mathrm{N}=10$, for all measurements. Habitus as shown in Figs. 3,4 .

Dark scaly patches on prothorax formed by bundles of suberect to erect slender scales only 
on anterior margin and on median prominences (Fig. 24). Black bands on eltyra composed of bundles of shorter, suberect scales (Figs. 25, 26); white bands composed of subrecumbent to suberect scales. Trochanter mingled with acicular scales in addition to lanceolate ones. Prosternal canal and meso- and metasterna moderately covered with scales, mingled with yellowish gray ones. Pygidium with erect white lanceolate scales, mixing with clavate ones.

Forehead (Fig. 14) 1.08 times as wide as rostrum. Rostrum (Figs. 14, 15) 1.37-1.44 times as long as prothorax. Antennae inserted just before middle of scape (Fig. 20) slenderer, 8.50 times as long as wide and 1.12 times as long as funicle; funicle (Fig. 19) relatively robust, with segment I 2.22 times as long as wide, 0.98 times as long as II, segment II 3.53 times as long as wide, segment III 2.30 times as long as wide, 0.71 times as long as II, segment IV 2.24 times as long as wide, 0.90 times as long as III, 1.37 times as long as V, segment V 1.64 times as long as wide, as long as VI, segment VI 1.36 times as long as wide, 0.97 times as long as VII, and segment VII 1.23 times as long as wide; club subrhomboidal. Prothorax (Fig. 24) 0.46-0.49 times as long as and 0.65-0.67 times as wide as elytra, 1.33-1.38 times as wide as long. Elytra 2.03-2.20 times as long as and 1.48-1.53 times as wide as prothorax, 1.02-1.07 times as long as wide. Fore femora 3.87 times as long as wide, 1.26 times as long as and 2.14 times as wide as fore tibiae; mid femora 3.79 times as long as wide, 1.40 times as long as and 2.29 times as wide as mid tibiae; hind femora 4.00 times as long as wide, 1.28 times as long as and 2.14 times as wide as hind tibiae. Fore tibiae (Fig. 30) 6.57 times as long as wide; corbels of fore tibiae scarcely dilated outward. Mid tibiae (Fig. 31) 6.14 times as long as wide. Hind tibiae (Fig. 32) 6.71 times as long as wide. Tarsal segment V (Fig. 34) relatively robust. Venter with ventrite II 0.40 times as long as I, 1.91 times as long as III, ventrite V 5.00 times as wide as long. Pygidium wider, 2.31 times as wide as long. Sternite IX (Fig. 49) with spiculum gastrale nearly as long as aedeagal body. Tegminal apodeme (Fig. 48) much wider, broadened apically. Aedeagal body (Figs. 46, 47) robust, subparallel-sided in basal half, then rapidly narrowed toward apex, bruntly projected at apex; apodeme longer, nearly as long as body. Endophallus (Fig. 46) with a large sclerite in middle and denser spicules in apical half. Otherwise practically as in C. squamatus.

Female. Length of body: 2.05-2.43 mm (mean $2.27 \mathrm{~mm}$ ). Length of rostrum: 1.05-1.20 $\mathrm{mm}$ (1.13). Maximum width of pronotum: $0.90-1.08 \mathrm{~mm}$ (1.00). Length of pronotum: $0.65-$ $0.80 \mathrm{~mm}$ (0.74). Maximum width of elytra: $1.35-1.63 \mathrm{~mm}$ (1.50). Length of elytra: $1.43-$ $1.70 \mathrm{~mm}(1.60) . \mathrm{N}=10$, for all measurements.

Rostrum (Fig. 16) longer, 1.48-1.62 times as long as prothorax. Prothorax 1.32-1.39 times as wide as long. Elytra 1.03-1.09 times as long as wide. Ventrite V 4.75 times as wide as long. Pygidium smaller and wider, 2.63 times as wide as long, sparsely covered with fine hairs and linear to clavate scales. Ovipositor as in Fig. 51. Sternite VIII (Fig. 50) furnished with very slender setae apically. Spermatheca (Fig. 52) with cornu bent downward at apex. Other sexual dimorphic traits as in C. squamatus female. 


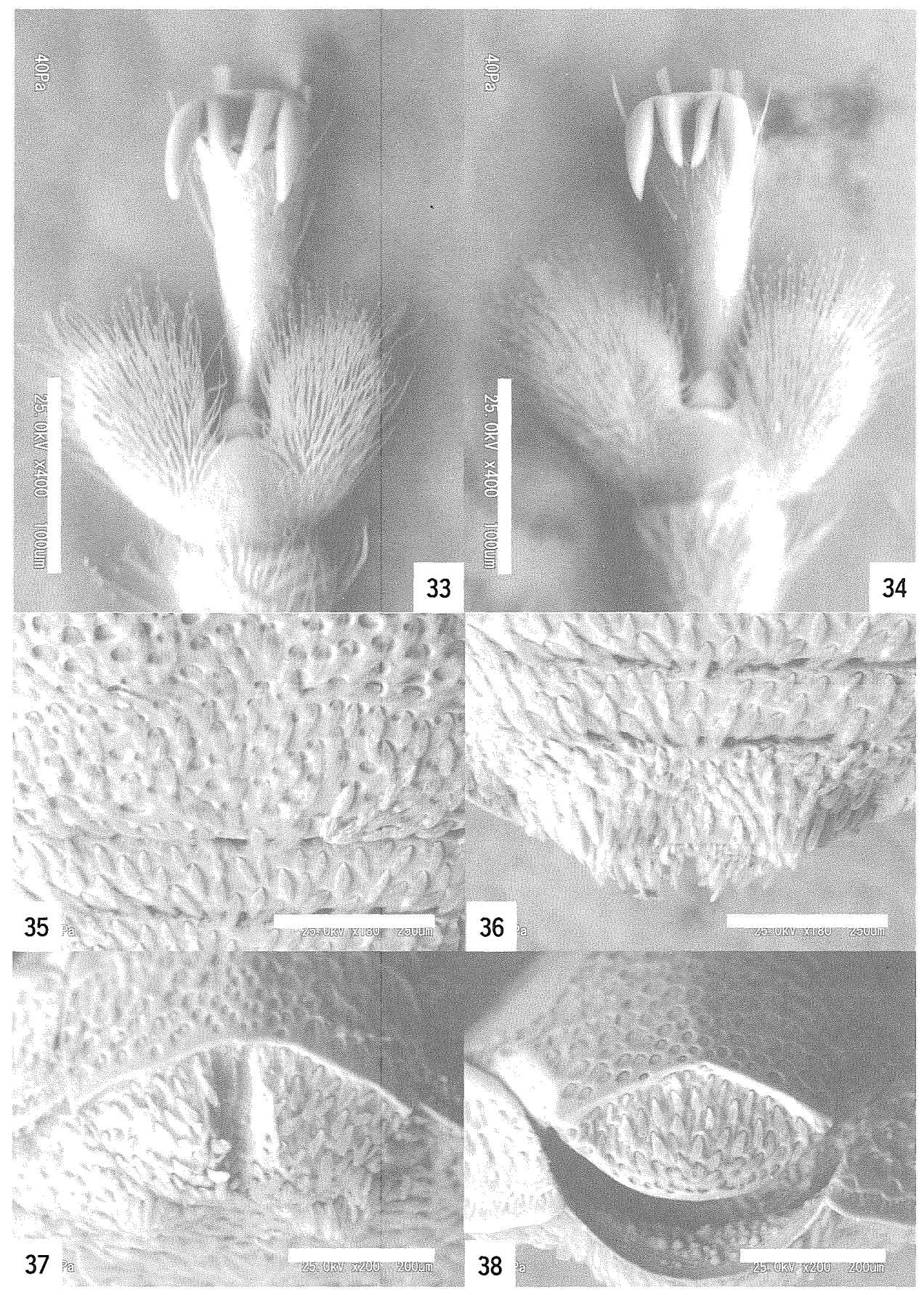

Figs. 33-38. Ceutorhynchoides spp. - 33, 35-38, C. squamatus sp. nov.; 34, C. styracis sp. nov.; 33,34 , claws; 35 , ventrites I-III, male; 36 , ventrites IV-V, male; 37 , pygidium, male; 38 , ditto, female. Scale: $0.10 \mathrm{~mm}$ for 33,$34 ; 0.25 \mathrm{~mm}$ for 35,$36 ; 0.20 \mathrm{~mm}$ for 37,38 . 
Type material. Holotype male (Type No. 3183, ELKU), Izumi, Yokohama, Kanagawa, Honshu, Japan, 6. vii. 1992, M. Horikawa (on Styrax japonica). Paratypes (EC, ELE, ELKU, HY, WPMNH). JAPAN: HONSHU. 1 female, Mizubashounomori, Shiroishi, Miyagi, 27. vi. 1994, H. Yoshitake. 2 males and 1 female, Mamiya, Urawa, Saitama, 13. viii. 1987, F. Fujita. 1 female, Ushiku, Kukisaki, Ibaraki, 25. iv. 1982, K. Emoto. 1 male, Ichikawa, Chiba, 2. vi. 1968, H. Yamazaki. Higashinaganuma, Inagi, Tokyo: 1 male and 2 females, 14. vi. 1986, A. Yoshida; 1 female, 26. vii. 1986, A. Yoshida; 1 female, 2. v. 1987, A. Yoshida. 2 males, Kawasaki, Kanagawa, 16. vii. 1999. 1 male and 1 female, Mt. Miurafuji, Yokosuka, Kanagawa, 17. vi. 1995, S. Kannou. 1 female, Noukendou, Yokohama, Kanagawa, 13. vii. 1990, S. Miyakawa. Izumi, Yokohama, Kanagawa: 3 males and 1 female, 19. iv. 1989, M. Horikawa (on Styrax japonica); 2 males, 9. vii. 1993, M. Horikwa (on Styrax japonica) 3 males and 3 females, Fukaya, Yokohama, Kanagawa, 30. iv. 1989, M. Horikawa (on Styrax japonica). 2 males and 2 females, Imada, Fujisawa, Kanagawa, 25. iv. 1989, M. Horikawa (on Styrax japonica). 1 male, Yamato, Kanagawa, 3. v. 1988, Y. Hirano. 1 female, Nenzaka, Sagamiko, Kanagawa, 14. v. 1996, K. Kubo. 1 female, Ohwakudani, Hakone, Kanagawa, 23. x. 1990, M. Horikawa. 1 female, Kamiyu, Hakone, Kanagawa, 17. v. 1991, M. Horikawa. 1 male, Suhara, Mino, Gifu, 16. viii. 1990, A. Ohashi. 2 males, Oda, Iga, Mie, 3. v. 1959, H. Hatooka. 1 male, Mt. Mayoidake, Miyagawa, Mie, 23. xi. 2000, T. Tenma. 1 female, Mt. Kongousan, Chihaya, Osaka, 28. v. 1989, K. Yoshihara. 3 females, GokurakubashiFudousaka, Mt. Kouyasan, Wakayama, 1. vii. 1989, K. Shigematsu. Kotonotaki, Susami, Wakayama: 1 male and 6 females, 25. viii. 1997, I. Matoba; 1 female, 9. vi. 1999, I. Matoba. Mt. Gomadan, Wakayama: 1 male, 11. v. 1985, H. Hiramatsu; 1 male, 8. v. 1993, I. Matoba; 1 female, 21. vi. 1993, I. Matoba. 2 females, Maenokawa, Wakayama, 10. vii. 1991, I. Matoba. 1 male, near Mt. Ohtou, Wakayama, 19. v. 1979, I. Matoba. 1 male, Ikenoyama, Kozagawa, Wakayama, 10. v. 1996, I. Matoba. 1 female, Tanagatani, Kumanogawa, Wakayama, 1. vii. 1999, I. Matoba. SHIKOKU. 1 female, Odamiyama, Ehime, 26. vii. 1967, K. Hatta. KYUSHU. 1 male, Mt. Hikosan, Fukuoka, 5. vii. 1992, H. Kojima. 1 female, Mt. Hattendake, Sasebo, Nagasaki, 22. iv. 1982, J. Okuma. 1 female, Inokodani, Kobayashi, Miyazaki, 20. v. 1990, A. Nagai. 1 female, Kyushu University Forest, Shiiba, Miyazaki, 2225. viii. 2003, H. Yoshitake.

Distribution. Japan (Honshu, Shikoku, Kyushu).

Biological notes. Ceutorhynchoides styracis, which has the northern most distribution range of the genus, is associated with Styrax japonica Siebold et Zuccarini (Styracaceae) in Honshu. The host plant is widely distributed in China, Korea, and Japan (Hokkaido, Honshu, Shikoku, Kyushu, and the Ryukyus), and constitutes the sub-canopy layer of warm- to cooltemperate forests. In Yokohama, Kanagawa Prefecture, many adults were captured on $S$. japonicus bearing flowers and unripe fruits in a deciduous and evergreen broad-leaved mixed forest, which was dominated in the canopy layer by Quercus serrata Thunberg ex Murray 

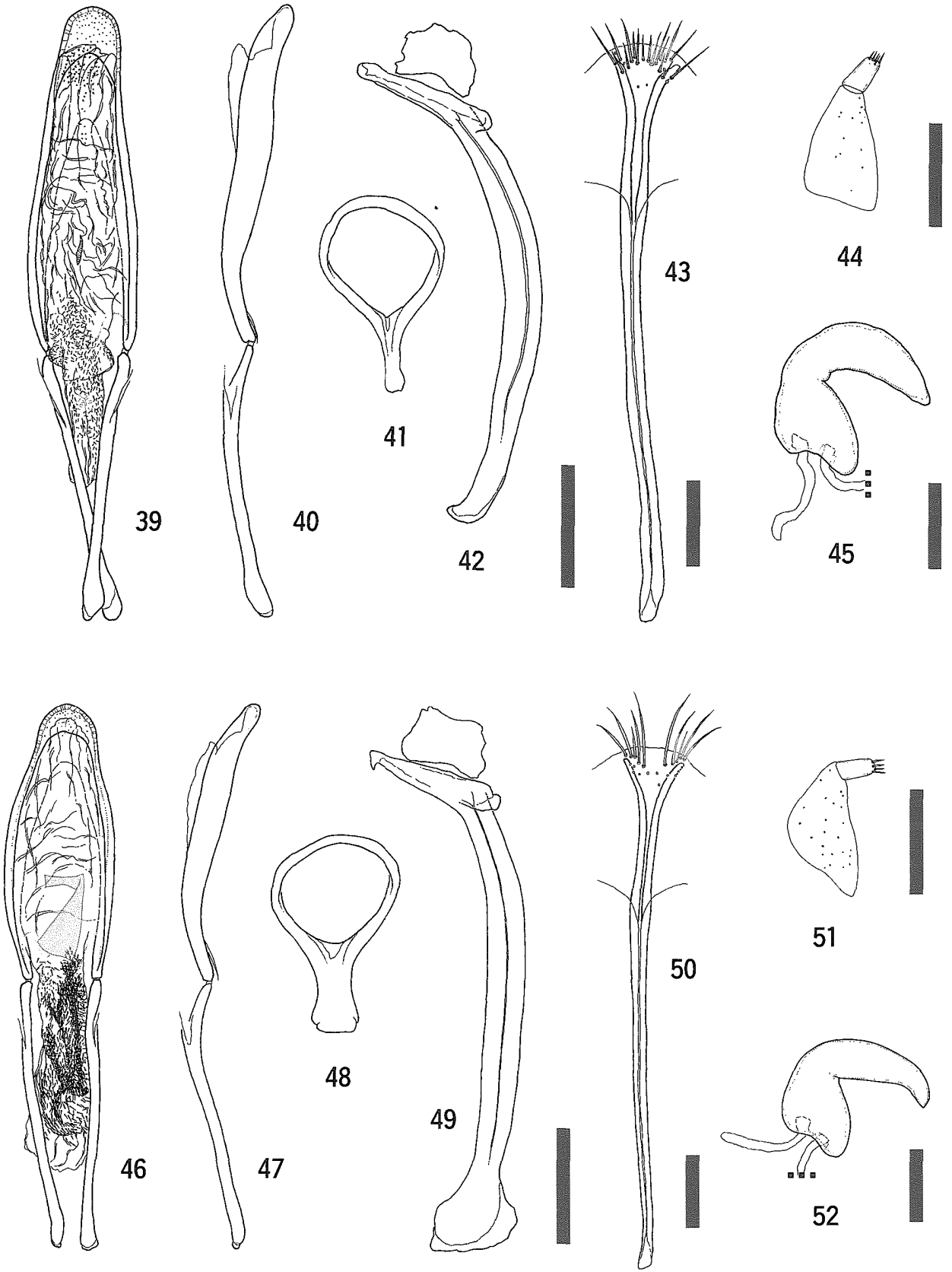

51

50

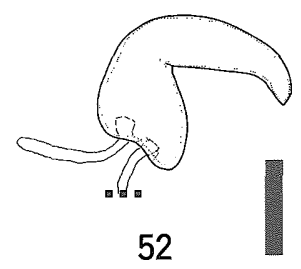

Figs. 39-52. Male and female genitalia of Ceutorhynchoides spp. -39-45, C. squamatus sp. nov.; 46-52, C. styracis sp. nov.; 39, 46, aedeagus, dorsal view; 40, 47, ditto, lateral view; 41 , 48, tegmen; 42, 49, sternite IX; 43, 50, sternite VIII; 44, 51, ovipositor; 45, 52, spermatheca; $39-42,46-49$, male; $43-45,50-52$, female. Scale: $1.00 \mathrm{~mm}$ for 39-42, 46-49; $0.50 \mathrm{~mm}$ for $43-45,50-52$. 
(Fagaceae), mixing with Castanopsis sieboldii (Makino) Hatusima ex Yamazaki et Mashiba (also Fagaceae) (M. Horikawa, 2000, pers. comm.). The type specimens were collected from lowlands to mountain areas.

Etymology. This species is named after the generic name of the host plant.

\section{Hainokisaruzo gen. nov.}

Type species: Hainokisaruzo japonicus sp. nov.

Diagnosis. Hainokisaruzo gen. nov. is related to Ceutorhynchoides in having the following features: pronotum with a pair of tubercles in middle; basal margin of pronotum serrate; basal margin of each elytron fringed with a row of long hairs; elytra with three dark bands of squamate tubercles; the sternal furrow diminished to a shallow median concavity on mesoand metasterna. However, this new genus can be readily distinguished from Ceutorhynchoides by the following characteristics: 1) body relatively slim (Figs. 5, 7, 9); 2) vestiture sparser, composed of narrow scales; 3) rostrum slenderer (Figs. 53-61); 4) antennal scape with a blunt apical process and with a hair or hair-like scale on dorsal surface of the process (Figs. 63, 65, 67) ; 5) antennal scrobes fused ventrally with each other (Figs. 54, 55, $57,58,60,61)$; 6) apical margin of pronotum not or scarcely raised; 7) basal margin of pronotum fringed with 1-2 rows of brownish narrow scales; 8) tubercles on elytra lessmarked; 9) each stria of elytra with a median row of minute hairs or scales; 10) tarsal claws widely separated by triangular teeth (Figs. 77, 78); ventrite V (Figs. 80, 82, 84) much narrower in both sexes. Also, this genus shows close resemblance to Coeliodes Schoenherr, 1837 and its allies in general appearance, but is distinctive enough not to be confused with those genera by the serrate basal margin of pronotum, besides the presence of discal tubercles on it.

Description. Reddish brown to dark brown in general appearance; basal margins of pronotum and elytra black. Body small, 1.75-2.18 mm in length, relatively slender, mostly clothed with sparse light-colored scales, lacking prominent scales, with less-marked dark scaly patches; each scale more or less narrow and weakly dilated toward apex. Head with a long median carina extending from vertex to base of forehead; forehead shallowly depressed, sparsely clothed with scales, fringed with suberect scales along internal margin of each eye. Rostrum (Figs. 53-61) slender, more than 1.55 times (male) or 1.70 times (female) as long as prothorax, clothed with linear scales near base; scales becoming minute and indistinct apically; apical part before level between antennal insertions nearly naked; dorsum with 3 glossy carinae, shallowly punctured along carinae; punctures becoming minute and sparse apically; antennal scrobes being on latero-ventral surface of rostrum and fused with each other on ventral surface. Antennae slender; scape (Figs. 63, 65, 67) clavate, produced in a short process at apex and furnished with a hair or hair-like scale on dorsal surface of process; funicle (Figs. 62, 64, 66) 7-segmented. Pronotum with a longitudinal sulcus along midline 


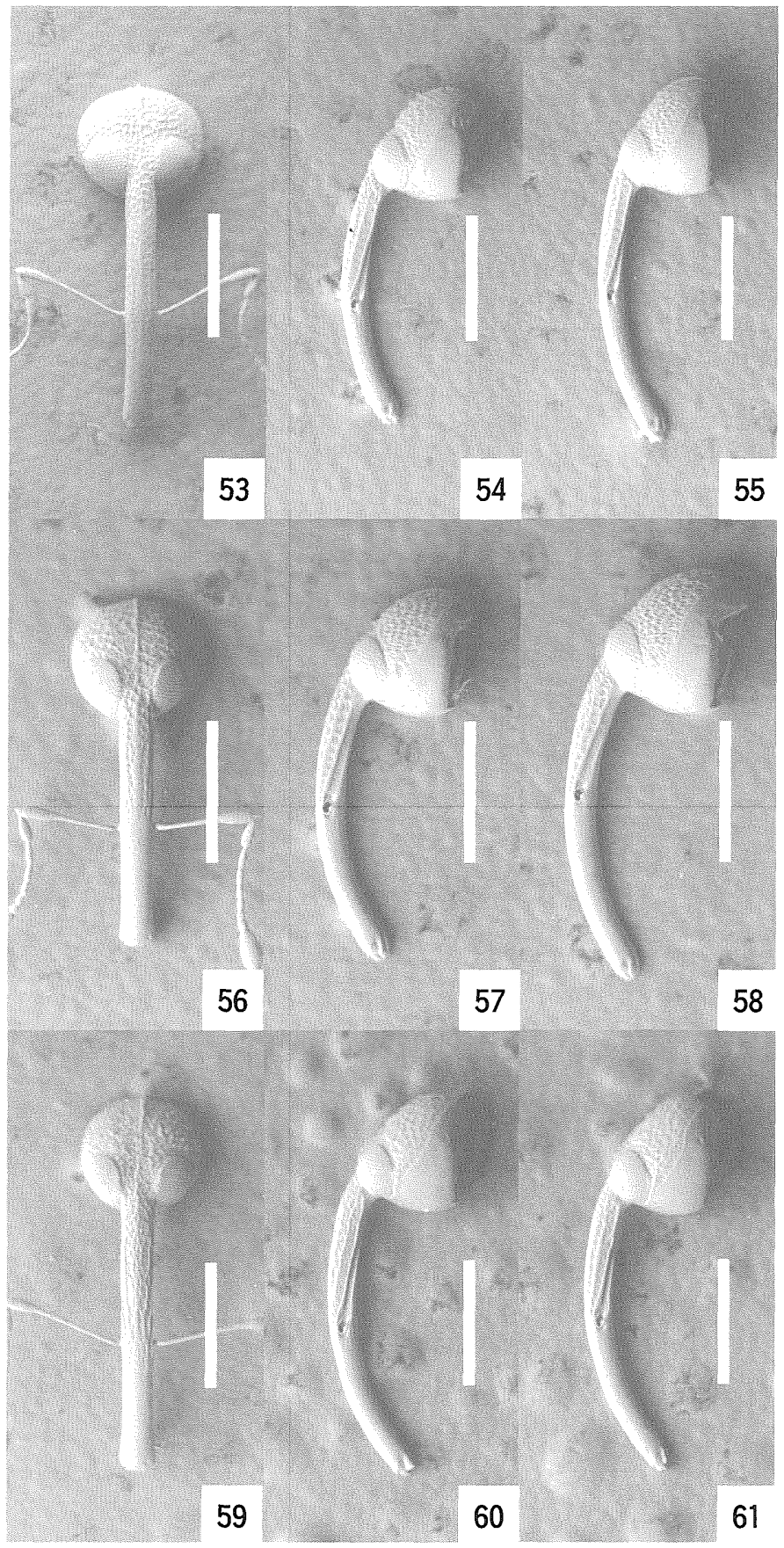

Figs. 53-61. Heads of Hainokisaruzo spp. $-53-55, H$. japonicus sp. nov.; 56-58, $H$. nipponensis (Hustache); 59-61, H. infuscatus sp. nov.; 53, 56, 59, dorsal view, male; 54, 57,60 , lateral view, male; 55, 58, 61, lateral view, female. Scale: $0.50 \mathrm{~mm}$. 
of disc, bearing a tubercle on each side of sulcus; tubercles furnished with dark-colored scales; apical margin more or less emarginate at middle, flattened or scarcely raised in profile; basal margin serrate, weakly bisinuate or nearly straight, strongly raised to either side of middle, fringed with 1-2 rows of brownish narrow scales; scales in each row directed basally. Scutellum linear to lanceolate, shining. Elytra moderately convex dorsally, with 3 transverse bands of tubercles in subbasal, median, and subapical parts; tubercles on odd numbered intervals, more or less weakly developed, and furnished with dark-colored scales; basal margin of each elytron fringed with a row of very long hairs; each row concealed by basal margin of pronotum when reposed; striae shining, with a row of minute hairs or scales on interspaces between punctures; each puncture round, separated by distance $2.00-4.00$ times as long as its diameter; intervals shining, much wider than striae; humeri well-developed. Legs slender; femora elongate and pedunculate in varying degrees, each armed with a small tooth; tooth concealed by light-colored scales, rarely vanished on fore legs; tibiae clothed with fine hairs in apical part; corbel of each tibia fringed with light-colored setae; claws (Figs. 77, 78) widely separated by a pair of triangular teeth. Prosternum with a deep rostral groove before coxae; groove limited laterally by keels; mesosternum and anterior part of metasternum shallowly depressed in middle for reception of rostrum. Metendosternite with short hemiductus. Tergite VII with a pair of minute plectral tubercles. Venter (Figs. 80, 82, 84) mostly opaque due to dense minute punctation; ventrites III and IV subequal in length. Male genitalia with sternite IX well-sclerotized (Figs. 93, 100, 107) and with aedeagal body more or less attenuate in profile (Figs. 92, 99, 106).

Distribution. India, China, Japan.

Etymology. The masculine generic name is formed by a combination of Japanese names of Symplocaceae trees "hainoki" and Ceutorhynchinae weevils "saruzo".

Comments. In addition to three new species from Japan, Hainokisaruzo contains the following six species: Hainokisaruzo nipponensis (Hustache, 1916), comb. nov. from Datonychus Wagner, 1944, and H. subcostulatus (Hustache, 1920), comb. nov., $H$. bengalensis (Colonnelli, 1984), comb. nov., H. notatus (Colonnelli, 1984), comb. nov., $H$. topali (Colonnelli, 1984), comb. nov., and H. sinensis (Korotyaev, 1989), comb. nov. from Ceutorhynchoides. These species have diagnostic features of this new genus. We examined type specimens of all of them except $H$. sinensis, of which one male specimen from Yunnan was studied. There are several undescribed species of this genus in India, Malaysia, Indonesia, and the Philippines.

\section{Hainokisaruzo japonicus sp. nov.}

Diagnosis. In having the similar body shape and scaly maculation, Hainokisaruzo japonicus sp. nov. appears to be related to $H$. sinensis, which was described on a single male specimen. 


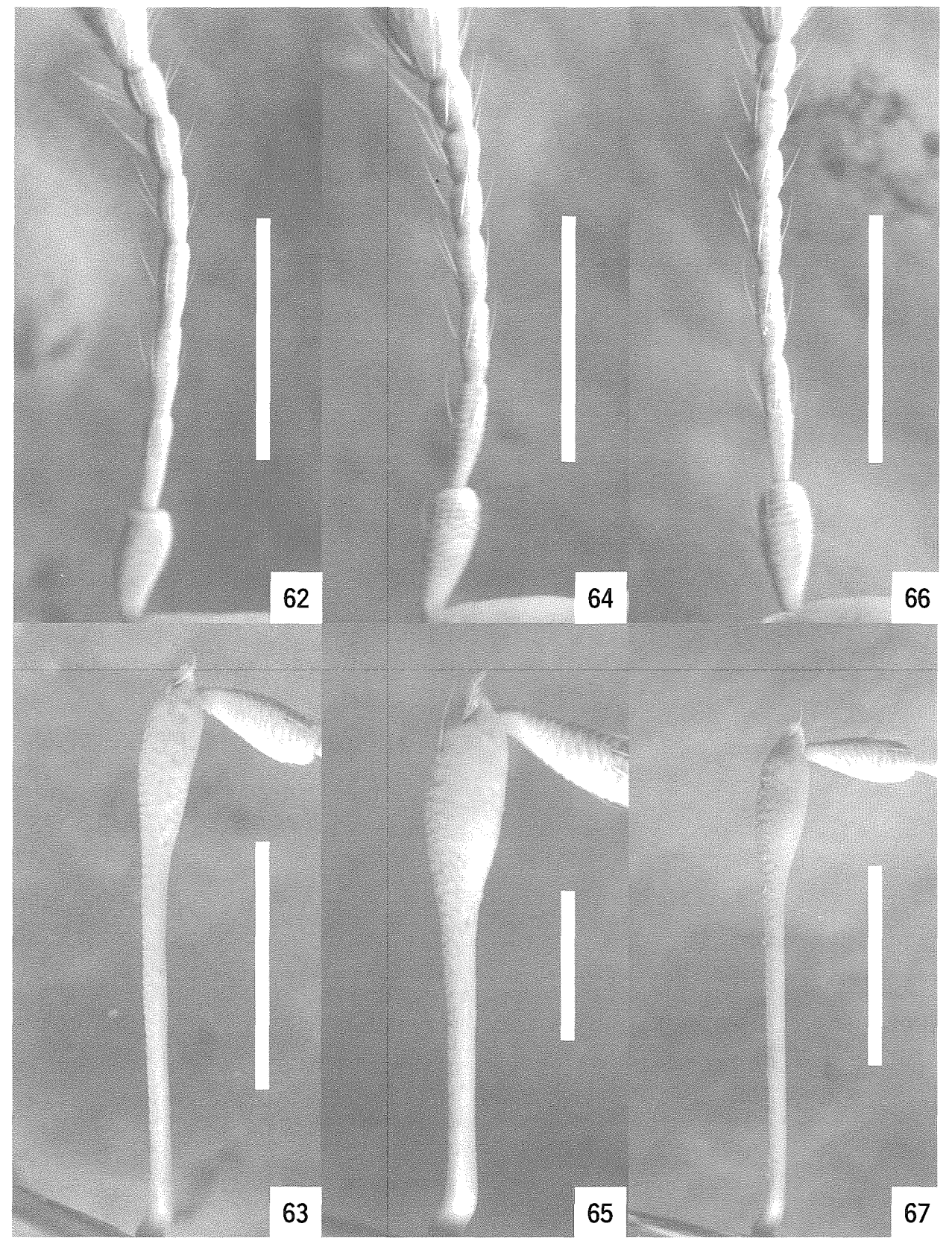

Figs. 62-67. Antennae of Hainokisaruzo spp. - 62, 63, H. japonicus sp. nov.; 64, 65, H. monticola sp. nov.; 66. 67, H. infuscatus sp. nov.; 62, 64, 66, funicles; $63,65,67$, scapes. Scale: $0.20 \mathrm{~mm}$ for $62,63,67 ; 0.25 \mathrm{~mm}$ for 64,$66 ; 0.30 \mathrm{~mm}$ for 67 . 
The affinity between the two species is emphasized by the prothorax with coarse, shallow and reticulate punctation, the elytral intervals evenly with minute granules, the small spiniform tooth on each femora, and the rounded-pentagonal pygidium in male (Fig. 85). However, $H$. japonicus is easily distinguished from $H$. sinensis by the shape of the male aedeagal body (Figs. 91, 92).

This new species has common characteristics to $H$. infuscatus sp. nov. and $H$. nipponensis as follows: head with a dark scaly patch in middle; sides of prothorax mingled with oval scales in addition to general scaling; elytra bearing three white scaly bands in antemedian, postmedian, and apical parts. Also, they share the male pygidium lacking longitudinal concavity (Figs. 85, 87, 89) and the female ventrite $\mathrm{V}$ with a shallow circular concavity in the middle. Because of its small size and light body color (Figs. 5, 6), however, this species is distinctive enough not to be confused with any other congeners from Japan. Besides the body size and coloration, the longer and wider prothorax, the robust femora, the short tibial corbels lacking outer dilation (Figs. 68-70), the bare area on flat disc of the male ventrite I (Fig. 79), and the subrhomboidal female pygidium (Fig. 86) are also useful for identification of $H$. japonicus.

Description. Male. Length of body: 1.75-1.90 mm (mean $1.86 \mathrm{~mm}$ ). Length of rostrum: 1.00-1.05 $\mathrm{mm}$ (1.01). Maximum width of pronotum: $0.78-0.85 \mathrm{~mm}(0.82)$. Length of pronotum: $0.60-0.65 \mathrm{~mm}$ (0.63). Maximum width of elytra: $1.20-1.25 \mathrm{~mm}$ (1.24). Length of elytra: $1.25-1.33 \mathrm{~mm}$ (1.28). $\mathrm{N}=10$, for all measurements. Habitus as shown in Figs. $5,6$.

Brown in general appearance; rostrum, antennae, and legs much paler and tinged with yellow.

Body surface evenly covered with ochreous powder in life. Head clothed with yellowish gray scales; scales slender, weakly dilated apicad, and becoming darker in middle of head; forehead mingled with linear ones. Rostrum clothed with white scales. Prothorax mostly covered with yellowish gray narrow scales; scales slightly dilated apcad, directed internally, and becoming darker and narrower in middle of pronotum; dorsum with a white patch of elliptic scales in antescutellar depression; sides mixed with white elliptic scales on lateroventral parts, in addition to general scaling. Elytra generally clothed with dark narrow scales in similar shape to those on prothorax, bearing 3 white scaly bands in antemedian, postmedian, and apical parts; apical band broadly connected with postmedian band except on intervals IV, V, VI, and VII; scales in each band slightly wider than general scaling; each interval with 1-3 rows of scales; interval I with a brown patch of elliptic scales at base; patch extending from base to basal $1 / 4$, followed by a smaller white patch, which is half as long as brown patch; interval II with a small white patch of elliptic scales at base; patch as long as one on interval I. Legs moderately covered with light-colored linear to narrow scales; corbel of each tibia fringed with golden-brown setae. Lateral pieces of meso- and metasterna densely squamate in upper 


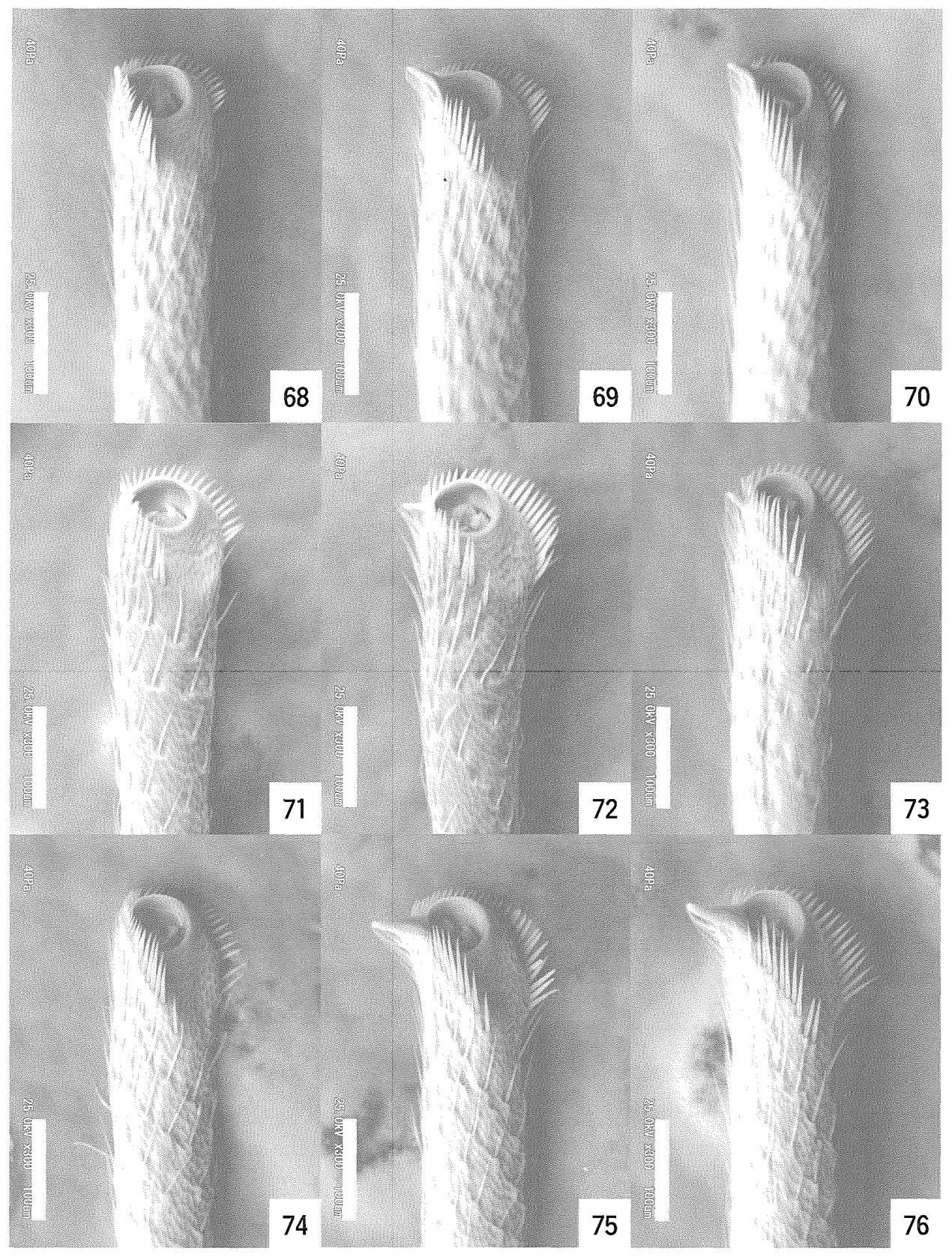

Figs. 68-76. Male tibiae of Hainokisaruzo spp. -68-70, $H$. japonicus sp. nov.; 71-73, $H$. nipponensis (Hustache); 74-76, H. infuscatus sp. nov.; 68, 71, 74, fore tibiae; 69, 72, 75, mid tibiae; 70, 73, 76, hind tibiae. Scale: $0.10 \mathrm{~mm}$. 
half, sparsely covered with white elliptic scales in lower half. Rostral groove on prosternum and meso- and metasterna covered with acicular to linear-lanceolate white scales. Metasternum mingled with fine hairs on disc. Venter (Figs. 79, 80) clothed with lanceolate white scales, except disc of ventrite I only with fine hairs; ventrite V mingled with fine hairs on disc. Pygidium (Fig. 85) thinly clothed with yellowish gray fine hairs.

Head (Fig. 53) coarsely and reticulately punctured; forehead 0.86 times as wide as rostrum. Rostrum (Figs. 53, 54) rather short, 1.58-1.67 times as long as pronotum, relatively thin and moderately curved; dorsum moderately punctured; punctures evident to apex, but minute especially in apical part before level between antennal insertions; sides slightly dilated from evidently constricted base, subparallel to antennal insertions, then narrowed toward apex. Antennae inserted before middle of rostrum (Fig. 54); scape (Fig. 63) considerably slender, as long as funicle and 10.22 times as long as wide, slightly projected at apex and with a hair on dorsal surface of projection; funicle (Fig. 62) with segment I 2.11 times as long as wide, 1.27 times as long as II, II 3.75 times as long as wide, III 3.50 times as long as wide, 0.93 times as long as II, IV 2.80 times as long as wide, as long as III, 1.27 times as long as V, V 2.20 times as long as wide, 1.16 times as long as VI, VI 1.73 times as long as wide, 1.05 times as long as VII, and VII 1.50 times as long as wide; club subrhomboidal, slightly constricted at base.

Prothorax 0.47-0.52 times as long as and 0.65-0.69 times as wide as elytra, 1.26-1.38 times as wide as long, widest at base, subparallel-sided in basal half, gradually narrowed toward apical $2 / 3$, then rather rapidly convergent toward subapical constrictions; dorsum coarsely and reticulately punctured, with a rather deep median sulcus, widely, strongly, and smoothly prominent; basal margin nearly straight.

Elytra 1.92-2.13 times as long as and 1.51-1.54 times as wide as prothorax, 1.00-1.06 times as long as wide, widest just behind humeri, slightly and gradually narrowed toward middle, then rapidly and straightly convergent toward subapical calli; striae shallow; each interval evenly with 1-4 rows of granules; prominences rather weak.

Fore femora 1.29 times as long as and 2.17 times as wide as fore tibiae, 4.08 times as long as wide. Mid femora 1.46 times as long as and 2.14 times as wide as mid tibiae, 3.60 times as long as wide. Hind femora 1.34 times as long as and 2.83 times as wide as hind tibiae, 3.24 times as long as wide. Fore tibiae (Fig. 68) 6.83 times as long as wide, minutely mucronate at apex; corbels short, simple, not dilated outward. Mid tibiae (Fig. 69) 5.29 times as long as wide, moderately mucronate at apex; corbels short, slightly dilated outward. Hind tibiae (Fig. 70) 6.83 times as long as wide, moderately mucronate at apex; corbels short, simple, not dilated outward. Tarsi (Fig. 77) with segment V robust; claws armed with sharp teeth.

Venter as in Figs. 79, 80; ventrite I closely punctured except disc; disc flat, shining, sparsely with small punctures; ventrite II closely and shallowly punctured in addition to general minute punctation, 0.35 times as long as I, nearly as long as III, shallowly concave on disc; ventrite $\mathrm{V}$ rather narrow, 2.64 times as wide as long, subequal in length with III and IV taken together, 


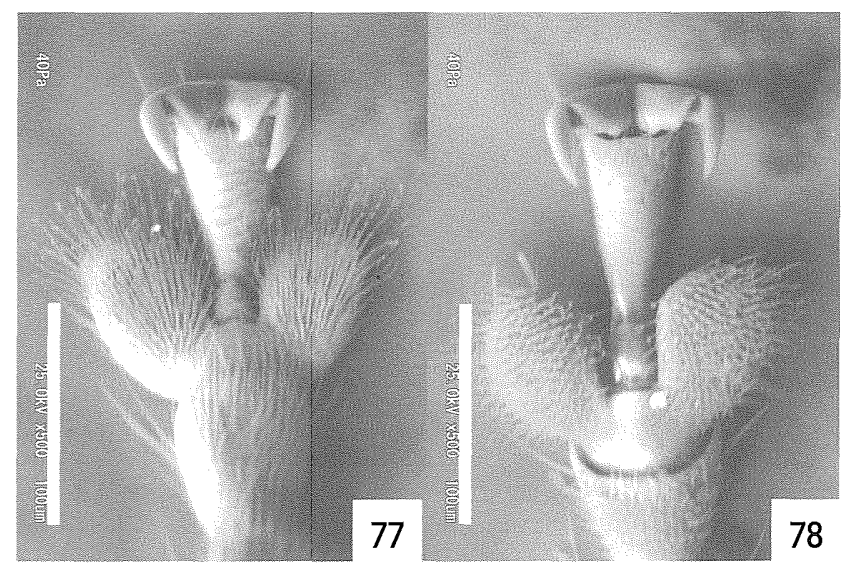

Figs. 77, 78. Claws of Hainokisaruzo spp. -77, H. japonicus sp. nov.; 78, H. nipponensis (Hustache). Scale: $0.50 \mathrm{~mm}$.

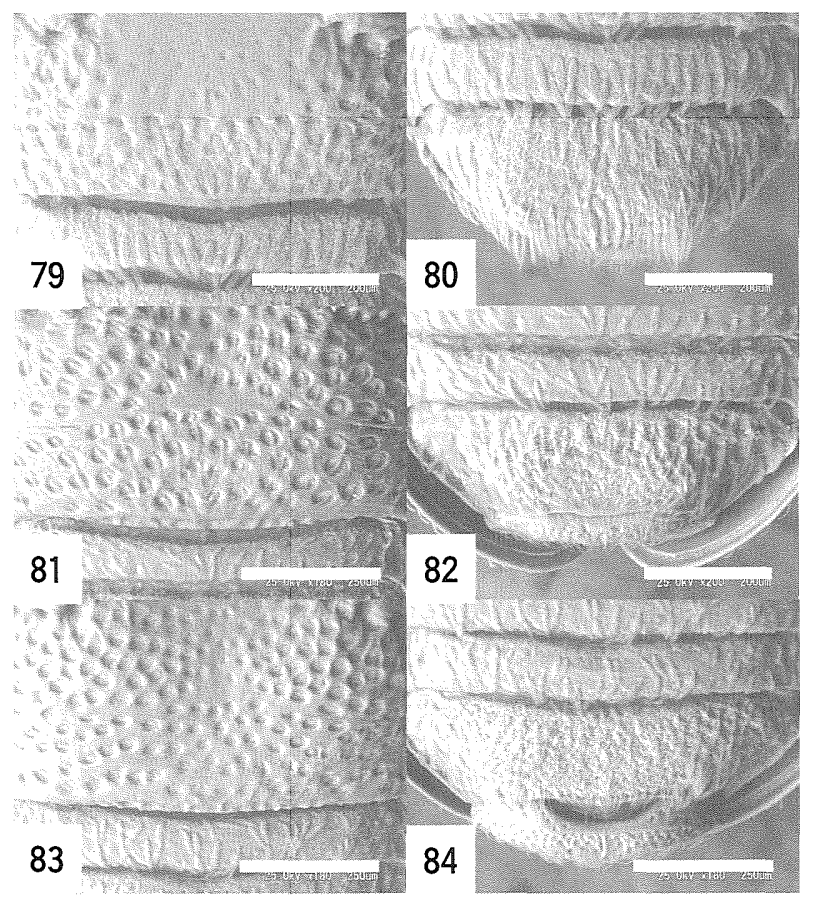

Figs. 79-84. Male ventrites of Hainokisaruzo spp. -79, 80, H. japonicus sp. nov.; 81, 82, H. nipponensis (Hustache); 83, 84, H. infuscatus sp. nov.; 79, 81, 83, ventrites I-III; 80, 82, 84 , ventrites IV-V. Scale: $0.20 \mathrm{~mm}$ for $79,80,82 ; 0.25 \mathrm{~mm}$ for $81,83,84$. 
with a wide and shallow semicircular concavity on disc.

Pygidium (Fig. 85) 1.68 times as wide as long, flat, lacking concavity, opaque due to minute punctures, sparsely with larger and shallower punctures than general punctation; upper flange evenly arched. Sternite IX (Fig. 93) longer than wide; spiculum gastrale slender, longer than aedeagal body or its apodeme, bent leftward. Tegmen (Fig. 94) with apodeme moderate in length, nearly $2 / 3$ as long as tegminal ring, robust, broadened toward apex. Aedeagal body (Figs. 91, 92) subparallel-sided in middle, slightly dilated toward base and strongly acuminate toward apex, relatively thin and bisinuate in profile. Endophallus (Fig. 91) with the following sclerites in addition to conical spicules: T-shaped and comma-shaped ones in basal part and plate-like one with serrate edge in middle; spicules concentrated and becoming larger in middle.

Female. Length of body: $1.75-2.03 \mathrm{~mm}$ (mean $1.89 \mathrm{~mm}$ ). Length of rostrum: 1.04-1.23 $\mathrm{mm}$ (1.13). Maximum width of pronotum: $0.78-0.90 \mathrm{~mm}(0.83)$. Length of pronotum: $0.60-$ $0.70 \mathrm{~mm}$ (0.64). Maximum width of elytra: $1.20-1.35 \mathrm{~mm}$ (1.27). Length of elytra of elytra: $1.20-1.40 \mathrm{~mm}$ (1.31). $\mathrm{N}=10$, for all measurements.

Rostrum (Fig. 55) 1.72-1.82 times as long as pronotum. Antennae inserted at middle of rostrum (Fig. 55). Prothorax 1.27-1.38 times as wide as long. Elytra 1.00-1.04 times as long as wide. Venter covered only with general scaling, lacking hairs; ventrites I and II slightly inflated; shiny area of ventrite I smaller; ventrite $\mathrm{V}$ wider, 2.93 times as wide as long. Pygidium (Fig. 86) subrhomboidal, 1.47 times as wide as long. Ovipositor (Fig. 96) with coxites slender, nearly 2.5 times as long as styli; styli apically inserted, slender, nearly 2.5 times as long as wide. Sternite VIII (Fig. 95) furnished with a pair of patches of slender setae at apex; arms robust, nearly $1 / 3$ as long as apodemes, as long as coxite and stylus combined, widely separated; apodemes slender, moderately divergent near apex. Spermatheca (Fig. 97) with cornu long, attenuate; collum broadly obliquely convex upward; ramus absent; insertions of duct and gland widely separated. Otherwise practically as in male.

Type series. Holotype male (Type No. 3181, ELKU), Kotonotaki, Susami, Wakayama, Honshu, Japan, 5. v. 2001, H. Yoshitake (on Symplocos glauca). Paratypes (EC, ELKU, HY, WPMNH). JAPAN: HONSHU. 12 males and 6 females, same data as the holotype. 1 female, Takiharaguu, Ohmiya, Mie, 21. iv. 1985, C. Ohkawa. Kotonotaki, Susami, Wakayama (on Symplocos glauca): 2 females, 25. viii. 1997, I. Matoba; 2 females, 18. vi. 1998, I. Matoba; 2 females, 24. iv. 1999, I. Matoba; 1 female, 9. vi. 1999, I. Matoba; 1 female, 18. viii. 1999, I. Matoba. 1 female, Mt. Kouyasan, Wakayama. 14. vii. 1996, I. Matoba. 1 female, Mt. Ohdaigahara, Nara, 22. v. 1982, H. Hiramatsu. KYUSHU. 2 males and 2 females, Mt. Yahirodake, Sasebo, Nagasaki, 27. iii. - 12. iv. 1983, J. Ohkuma.

Distribution. Japan (Honshu, Kyushu).

Biological notes. This species is associated with Symplocos glauca (Thunberg) Koidzumi (Symplocaceae) in Kii Peninsula, Honshu. The host plant is distributed in Indochina, China, 


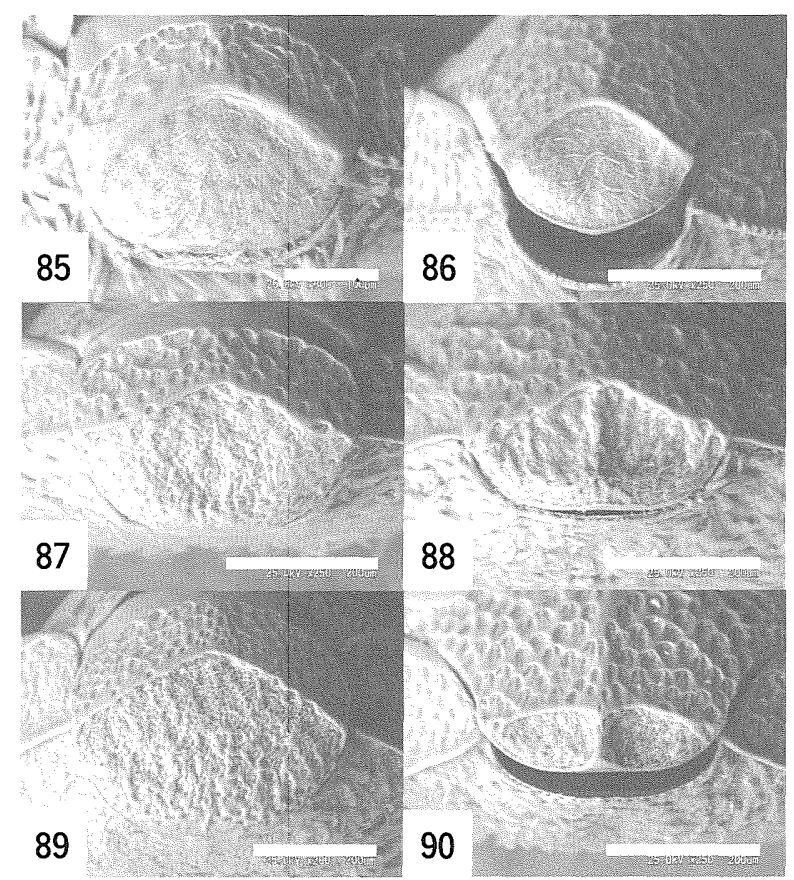

Figs. 85-90. Pygidia of Hainokisaruzo spp. - 85, 86, H. japonicus sp. nov.; 87, 88, $H$. nipponensis (Hustache); 89, 90, H. infuscatus sp. nov.; 85, 87, 89, male; 86, 88, 90, female. Scale: $0.10 \mathrm{~mm}$ for $85 ; 0.20 \mathrm{~mm}$ for $86-90$.
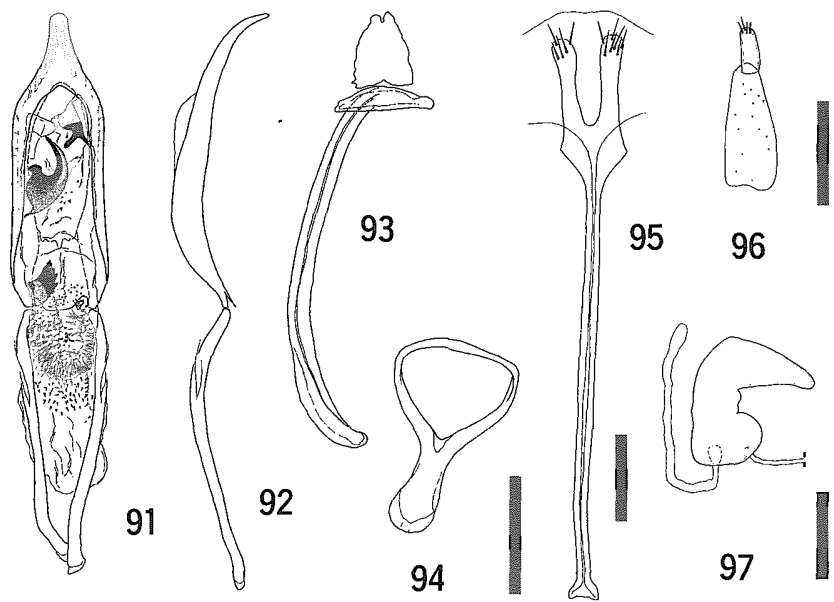

95

96

Figs. 91-97. Male and female genitalia of Hainokisaruzo japonicus sp. nov. -91, Aedeagus, dorsal view; 92, ditto, lateral view; 93, sternite IX; 94, tegmen; 95, sternite VIII; 96, ovipositor; 97 , spermatheca; $91-94$, male; $95-97$, female. Scale: $1.00 \mathrm{~mm}$ for $91-94 ; 0.50 \mathrm{~mm}$ for 95-97. 
and Japan (Honshu, Shikoku, Kyushu, and the Ryukyus), and constitutes the sub-canopy or shrub layers of warm-temperate forests. In Kotonotaki, Wakayama Prefecture, many adults were captured on $S$. glauca trees in an evergreen broad-leaved forest dominated by Castanopsis sieboldii (Makino) Hatusima ex Yamazaki et Mashiba (Fagaceae) and Quercus glauca Thunberg ex Murray (also Fagaceae) in the canopy layer. They were observed to feed on leaves of $S$. glauca. The type specimens were collected in warm-temperate forests from lowland to mountain areas.

Etymology. The specific name refers to the country where this new species occurs.

Hainokisaruzo nipponensis (Hustache, 1916), comb. nov.

Ceuthorrhynchus nipponensis Hustache, 1916, 141 (type locality: Japon moyen; Chûzenji) . Dalla Torre \& Hustache, 1930, 80 (in catalog). - Morimoto, 1962, 193 (in checklist); 1984, 317 (in key).

Ceuthorhynchus nipponensis: Morimoto, 1989, 513 (in checklist). - Yoshitake et al., 2004, 101 (in checklist).

Datonychus ?nipponensis: Colonnelli, 2004, 58.

Diagnosis. Besides the similar body shape and scaly maculation, Hainokisaruzo nipponensis (Hustache) is related to $H$. infuscatus in having the definitely delineated elytral striae, the presence of elytral granules only on tubercles, the absence of mucro at the apex of male fore tibiae (Figs. 71, 74), the obtuse teeth between claws (Fig. 78), the rounded apex of female ventrite $\mathrm{V}$, and the rugosely punctured pygidium in male (Figs. 87, 89). The affinity between the two species is emphasized also by the similarity in the male and female genitalic structures (Figs. 98-101, 105-108). However, it can be easily distinguished from H. infuscatus by the narrower forehead, the thicker rostrum with moderate punctation (Figs. 56, 57), the plump prothorax with coarse punctation, shallow median sulcus, and blunt prominences, the elytra bearing rather weak prominences, and the legs with slender femora and robust tibiae. In addition, the following features will also serve for identification of $H$. nipponensis: antennal scape (Fig. 65) robust, with a slender scale at apex; antennal funicle (Fig. 64) with thicker segment II; mucrones of mid and hind tibiae (Figs. 72, 73) smaller; tarsal segment V (Fig. 78) slenderer; ventrite V (Fig. 82) narrower in male and wider in female; male pygidium (Fig. 87) broadly concave in the middle; female pygidium (Fig. 88) larger, transversepentagonal, bearing an indefinite median carina.

Description. Malle. Length of body: 1.90-2.03 mm (mean $1.95 \mathrm{~mm}$ ). Length of rostrum: $0.98-1.00 \mathrm{~mm}$ (0.98). Maximum width of pronotum: $0.75-0.83 \mathrm{~mm}$ (0.78). Length of pronotum: $0.55-0.58 \mathrm{~mm}(0.56)$. Maximum width of elytra: $1.20-1.30 \mathrm{~mm}$ (1.24). Length of elytra: $1.40-1.50 \mathrm{~mm}(1.44) . \mathrm{N}=3$, for all measurements. Habitus as shown in Figs. $7,8$. 

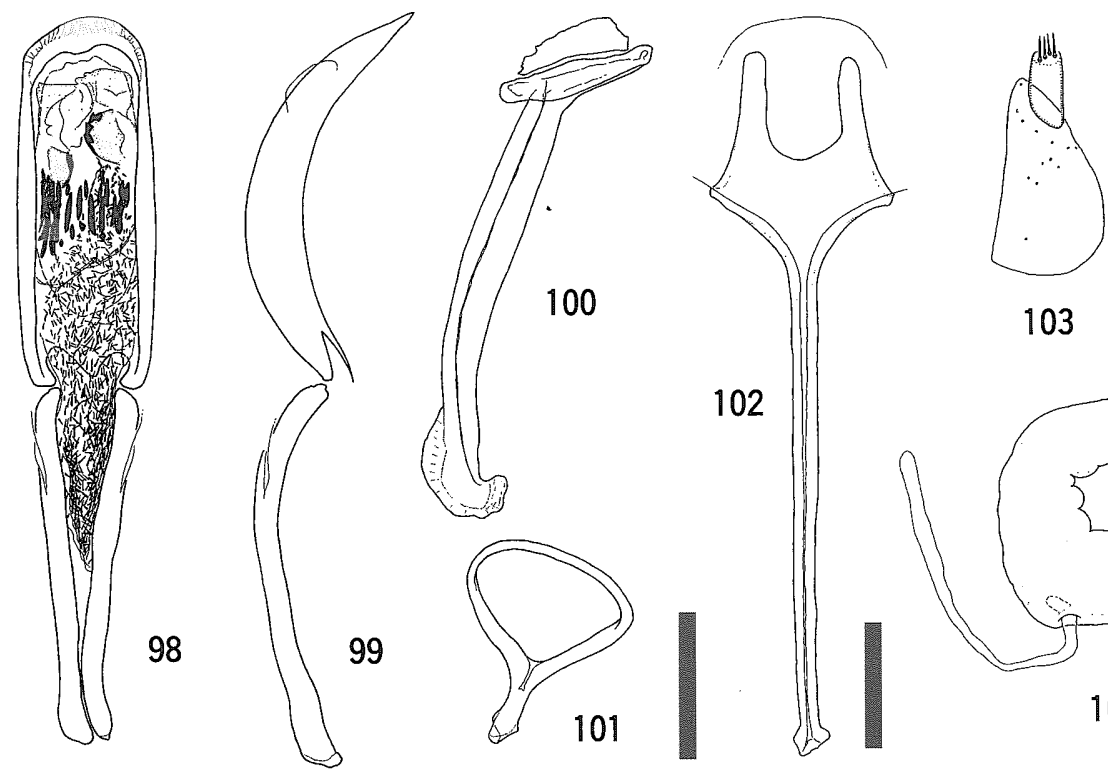

100

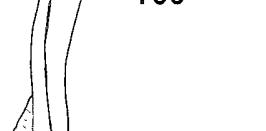

98
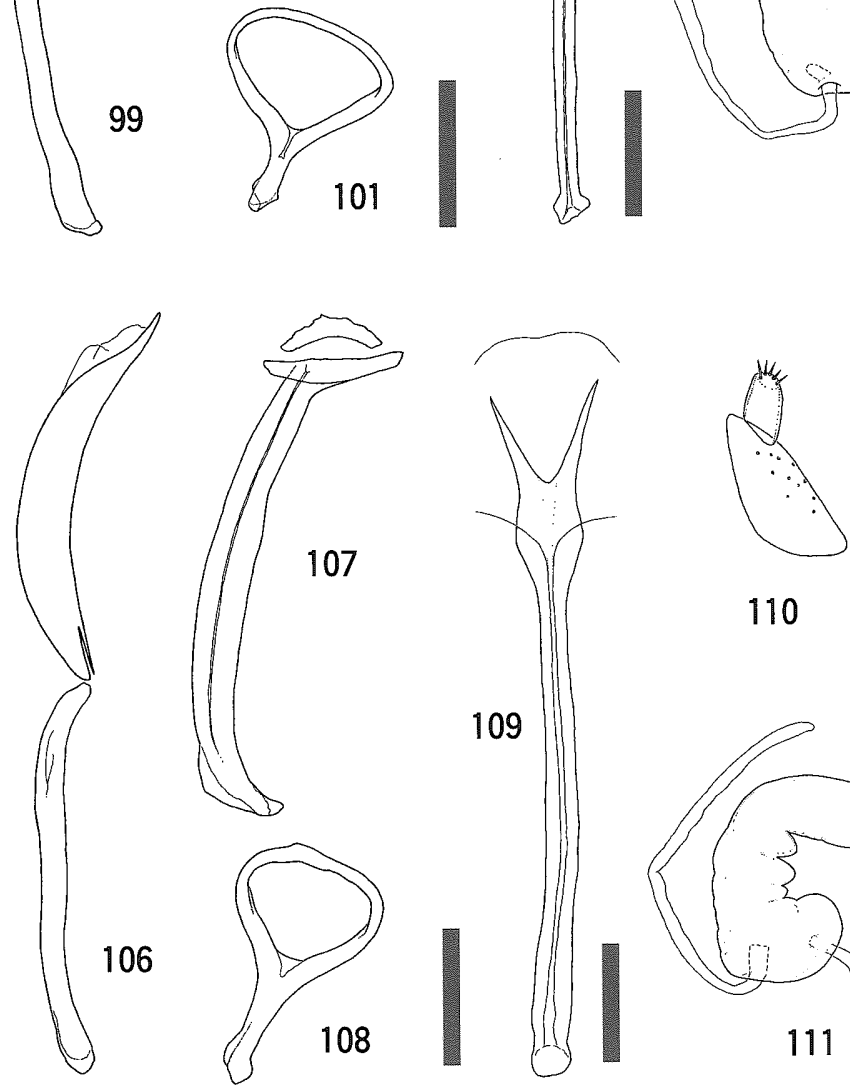

110

103
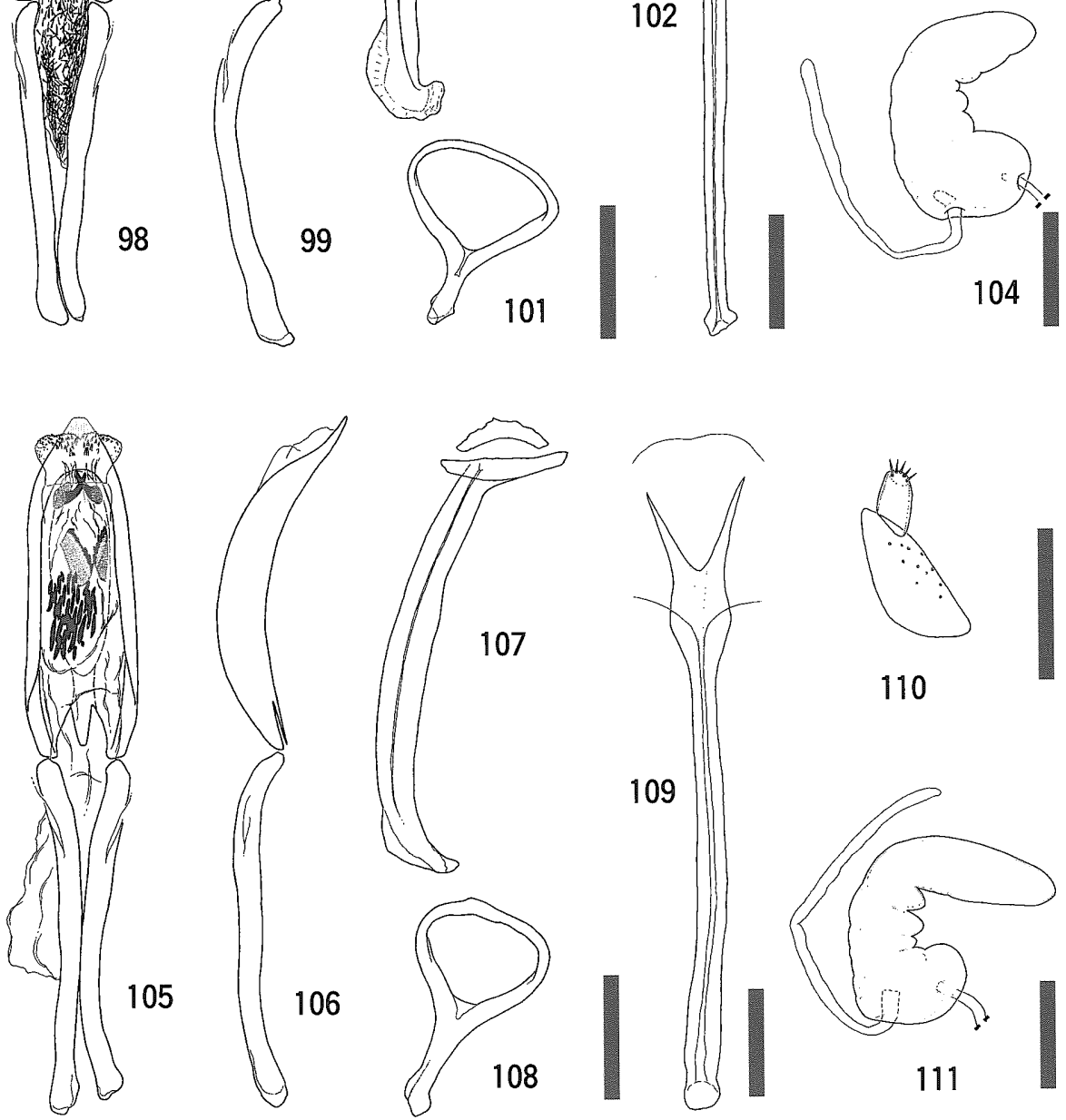

Figs. 98-111. Male and female genitalia of Hainokisaruzo spp. -98-104, H. nipponensis (Hustache); 105-111, H. infuscatus sp. nov.; 98, 105, aedeagus, dorsal view; 99, 106, ditto, lateral view; 100, 107, sternite IX; 101, 108, tegmen; 102, 109, sternite VIII; 103, 110 , ovipositor; 104,111 , spermatheca; $98-101,105-108$, male; 102-104, 109-111, female. Scale: $1.00 \mathrm{~mm}$ for $98-101,105-108 ; 0.50 \mathrm{~mm}$ for $102-104,109-111$. 
Dark brown in general appearance; basal half of rostrum and legs reddish brown; antennae and apical half of rostrum much paler; elytral suture and venter tinged with black.

Body surface evenly covered with ochreous powder in life. Head clothed with white scales; scales relatively broad, weakly dilated apicad, becoming darker in middle; forehead mingled with linear ones. Rostrum clothed with white scales. Prothorax mainly clothed with narrow and elliptic white scales; narrow scales similar to those on head in shape, becoming fine medially; dorsum with a dark area of brownish narrow scales; dark area bisected by a median white stripe, which is composed of elliptic scales in basal $1 / 3$ and narrow ones in remaining $2 / 3$; sides covered with narrow and elliptic white scales; white stripe on dorsum and white scaly area on each side often connected by subbasal oblique and subapical transverse white bands of narrow scales. Elytra generally clothed with brownish narrow scales in similar shape to those on prothorax, bearing a white patch of elliptic and narrow scales at base between intervals I-IV, in addition to 3 white scaly bands in antemedian, postmedian, and apical parts; each band composed of narrow and elliptic scales; apical band connected with postmedian band on intervals I, II, IX, and X; each interval with 1-4 rows of scales. Legs moderately covered with white narrow to lanceolate scales; corbel of each tibiae fringed with yellowish gray setae. Lateral pieces of meso- and metasterna moderately covered with white elliptic and lanceolate scales. Rostral groove on prosternum and meso- and metasterna covered with lanceolate to linear-lanceolate white scales; metasternum only with scales, lacking hairs. Venter (Figs. 81, 82) clothed with elliptic and lanceolate white scales; ventrite I only with scales, lacking hairs; ventrite V sparsely with fine hairs and minute scales on disc. Pygidium (Fig. 87) moderately clothed with yellowish gray fine hairs.

Head finely and closely punctured; forehead narrow, 0.92 times as wide as rostrum. Rostrum (Figs. 56, 57) slender, 1.74-1.77 times as long as pronotum, relatively thick, and rather strongly curved before apex; dorsum moderately punctured; punctures indistinct on apical half. Antennae inserted at middle of rostrum (Fig. 57); scape (Fig. 65) short and robust, 0.86 times as long as funicle and 6.14 times as long as wide, produced in a short lamina at apex; lamina with a hair-like scale on dorsal surface; scale followed by a slender hair; funicle (Fig. 64) with segment I 2.54 times as long as wide, 1.22 times as long as II, II 3.38 times as long as wide, III 2.5 times as long as wide, 0.74 times as long as II, IV twice as long as wide, 0.90 times as long as III, 1.29 times as long as V, V 1.56 times as long as wide, 1.08 times as long as VI, VI 1.30 times as long as wide, as long as VII, VII 1.08 times as long as wide; club subrhomboidal, not constricted at base.

Prothorax 0.38-0.39 times as long as and 0.61-0.64 times as wide as elytra, 1.36-1.43 times as wide as long, widest near base, gradually narrowed toward apical 1/4, then strongly convergent toward subapical constriction; dorsum coarsely and moderately punctured, with a shallow median sulcus, narrowly and moderately prominent; basal margin weakly bisinuate.

Elytra 2.55-2.60 times as long as and 1.57-1.64 times as wide as pronotum, 1.15-1.17 times 
as long as wide, widest just behind humeri, subparallel-sided in basal half, then moderately convergent toward subapical calli; striae rather deep; intervals relatively wide, with granules evident only on prominences; prominences moderate in height.

Each femur armed with a vestigial tooth. Fore femora 5.20 times as long as wide, 1.27 times as long as and 1.67 times as wide as fore tibiae. Mid femora 4.33 times as long as wide, 1.37 times as long as and 2.00 times as wide as mid tibiae. Hind femora 4.08 times as long as wide, 1.33 times as long as and 2.17 times as wide as hind tibiae. Fore tibiae (Fig. 71) 6.83 times as long as wide, simple at apex, lacking mucro; corbels short, simple, not dilated outward. Mid tibiae (Fig. 72) 6.33 times as long as wide, each armed with a small mucro at apex; corbels moderate in length, slightly dilated outward. Hind tibiae (Fig. 73) 6.67 times as long as wide, with apices as in mid legs. Tarsi (Fig. 78) with segment V slender; claws armed with obtuse teeth.

Venter as in Figs. 81, 82; ventrite I coarsely and closely punctured, shallowly concave on disc; ventrite II 0.56 times as long as I, twice as long as III, coarsely and closely punctured, conjointly concave with I; ventrite $\mathrm{V}$ relatively narrow, 3.64 times as wide as long, shorter than III and IV taken together, with a shallow transverse concavity in apical half of disc.

Pygidium (Fig. 87) 1.85 times as wide as long, opaque, rugosely punctured, with a shallow concavity in middle; upper flange arcuate downward on each side. Sternite IX (Fig. 100) much wider than long; spiculum gastrale relatively robust, longer than aedeagal body or its apodeme, bent leftward. Tegmen with apodeme (Fig. 101) short, nearly $1 / 3$ as long as tegminal ring, thin, subpallarel-sided. Aedeagal body (Figs. 98, 99) broad, subparallel-sided, weakly constricted near apex, broadly and asymmetrically rounded at apex, relatively thick and strongly curved downward in profile. Endophallus (Fig. 98) with many bars of sclerites and 2 plate-like ones in basal part, in addition to acicular spicules; spicules numerous, distributed in apical $2 / 3$, concentrated and becoming larger apically.

Female. Length of body: 1.95-2.10 mm (mean $2.05 \mathrm{~mm}$ ). Length of rostrum: 1.05-1.08 $\mathrm{mm}$ (1.06). Maximum width of pronotum: $0.83-0.85 \mathrm{~mm}(0.84)$. Length of pronotum: $0.58-$ $0.60 \mathrm{~mm}(0.59)$. Maximum width of elytra: $1.33-1.38 \mathrm{~mm}$ (1.36). Length of elytra: $1.48-$ $1.53 \mathrm{~mm}$ (1.51). $\mathrm{N}=7$, for all measurements.

Rostrum (Fig. 58) much slenderer, 1.75-1.83 times as long as prothorax. Antennae inserted behind middle of rostrum (Fig. 58). Prothorax 1.38-1.44 times as wide as long. Elytra 1.091.15 times as long as wide. Mid and hind tibiae faintly mucronate at apex. Ventrites I and II slightly inflated, evenly and finely punctured. Ventrite V wider, 3.63 times as wide as long, with an elliptic concavity on disc, rounded at apex. Pygidium (Fig. 88) wider, 2.03 times as wide as long, depressed, with a median carina extending from upper flange to lower margin. Ovipositor (Fig. 103) with coxites robust, nearly twice as long as styli; styli apicolaterally inserted, moderate in length, nearly twice as long as wide. Sternite VIII (Fig. 102) simple, lacking setae; arms robust, nearly half as long as apodemes, slightly longer than coxite and 
stylus combined, very widely separated; apodemes moderate in length, markedly divergent near apex. Spermatheca (Fig. 104) with cornu robust, moderate in length, widely rounded at apex; collum broadly obliquely convex upward; ramus absent; insertions of duct and gland widely separated. Otherwise practically as in male.

Specimens examined. JAPAN: HONSHU. Holotype female (MNHN), JAPON. Chû-/ zenji: 21-7-10/Edme Gallois (yellow label); MUSEUM PARIS / NIPPON MOYEN/E. GALLOIS 1913; Ceutorhynchus / nipponensis / type Hust. (hand written); Holotypus / Ceutorhynchoides / nipponensis (Hust.) (red label, partially hand written); Korotyaev det. 1985. 1 female, Mt. Komagatake, Hakone, Kanagawa, 29. v. 1992, M. Horikawa. 2 males, Shaka-shindou, Mts. Hakusan, Ishikawa, 31. vii. 2002, N. Takahashi. 1 male and 2 females, same data as the holotype. Same locality as the holotype (on Symplocos chinensis): 1 male, 19. vi. 2002, Kazuyoshi Izawa; 1 male and 4 females, 2. vii. 2002, H. Yoshitake; 1 male, 29. vi. 2003, Kazuyoshi Izawa. 1 female, Lake Hakusuiko, 1250-1340 m, Shirakawa, Gifu, 29. vi. 2002, K. Morimoto. 1 male, Sunomata, Kiyomi, Gifu, 18. v. 1991, T. Nohira. 1ex., Sakamototouge, 970 m, Kiyomi, Gifu, 22. v. 1972, T. Nohira. 1 female, Dando, Shitara, Aichi, 29. viii. 1989, H. Kojima. Mennokienchi, Tsugu, Aichi: 1 female, 1000 m, 8. ix. 2000, K. Izawa; 1 female, $1,100 \mathrm{~m}, 27$. vi. 2001, K. Izawa. 1 female, Mt. Chausuyama, $1400 \mathrm{~m}$, Toyone, Aichi, 12. viii. 1993, K. Izawa. Mt. Hirasan, Shiga: 10 exs., 28. v. 1956, T. Nakane; 2 females, 29. v. 1956, T. Nakane; 1 female, Yakumogahara, 22. vii. 1982, K. Masaki. 1 female, Seriodani, Kyoto, 3. vi. 1951, T. K. 1 male and 1 female, Sugitouge, Kyoto, 19. v. 1956, T. Kishii. 1 female, Mt. Kouyasan, Wakayama, 14. vii. 1996, I. Matoba. KYUSHU. 2 females, Mt. Fugendake, Mts. Unzen, Nagasaki, 4. vi. 1967, S. Hisamatsu. 1 female, Mt. Myouken, Mts. Unzen, Nagasaki, 4. vi. 1967, S. Hisamatsu. 1 female, Mt. Shiraiwa, Gokase, Miyazaki, 22. v. 1998, H. Kojima.

Distribution. Japan (Honshu, Kyushu).

Biological notes. This species is associated with Symplocos chinensis (Loureiro) Druce (Symplocaceae) in Gifu Prefecture, Central Honshu. The host plant is widely distributed in China, Korea, and Japan (Hokkaido, Honshu, Shikoku, and Kyushu), and constitutes the understory of warm- to cool-temperate forests, especially in wet locations such as riversides and marsh edges. In Ohshirakawa, Gifu Prefecture, many adults were captured on flowering shrubs of $S$. chinensis, which were growing around a small marsh in a deciduous broad-leaved forest dominated in the canopy layer by Fagus crenata Blume (Fagaceae) and Quercus mongolica Fischer var. grosseserrata (Blume) Rehder et Wilson (also Fagaceae). They were observed to feed on flowers and leaves of S. chinensis. The specimens examined were collected only from mountain areas at an elevation of 600-1500 m.

Comments. This species was transferred temporarily from Ceutorhynchus to Datonychus Wagner, 1944 by Colonnelli (2004), since he could not examine the holotype due to a longterm loan. The single female holotype slightly differs from other specimens examined in 
structures of rostrum and prothorax. Future examination of male specimens from the type locality is needed to understand intraspecific variation.

\section{Hainokisaruzo infuscatus sp. nov.}

Diagnosis. Hainokisaruzo infuscatus sp. nov. has certain relation to $H$. nipponensis, considering similarity of the two species in general appearance and structures of male and female genitalia. However, this species clearly differs from $H$. nipponensis in the wider forehead (Fig. 59), the slenderer rostrum with wrinkled punctation (Fig. 59), the slim prothorax with fine punctation and acute prominences, the rather strong prominences on elytra, and the robust femora and slender tibiae. In addition, the following features will serve for identification of H. infuscatus: antennal scape (Fig. 67) slender, with a long hair at apex; antennal funicle (Fig. 66) with segment II slender; mid and hind tibiae (Figs. 75, 76) with large apical mucrones; tarsomere V robust; ventrite V (Fig. 84) wide in male and narrow in female; male pygidium (Fig. 89) lacking median concavity; female pygidium (Fig. 90) small, eye-shaped, bearing a definite median carina.

Description. Male. Length of body: 2.03-2.18 mm (mean $2.09 \mathrm{~mm}$ ). Length of rostrum: 1.10-1.23 mm (1.15). Maximum width of pronotum: $0.80-0.88 \mathrm{~mm}$ (0.82). Length of pronotum: $0.63-0.68 \mathrm{~mm}$ (0.64). Maximum width of elytra: $1.30-1.45 \mathrm{~mm}$ (1.35). Length of elytra: $1.45-1.58 \mathrm{~mm}(1.49)$. $\mathrm{N}=7$, for all measurements. Habitus as shown in Figs. 9,10 .

Dark brown in general appearance; rostrum, legs, and pygidium brown; antennae and tarsi much paler; elytral suture and prominences tinged with black.

Body surface covered with white powder in part on prothorax and elytra. Head clothed with wider scales than those of $H$. nipponensis. Elytra with apical band broadly connected with postmedian band except on intervals III, V, VII, and IX. Rostral groove covered with acicular to linear-lanceolate scales on pro-, meso- and metasterna. Venter (Figs. 83, 84) clothed with acicular to lanceolate scales; ventrite V. densely with fine hairs and minute scales on disc. Pygidium (Fig. 89) moderately clothed with white fine hairs, mingled with elliptic scales.

Forehead (Fig. 59) 1.06 times as wide as rostrum. Rostrum (Figs. 59, 60) considerably slender, 1.73-1.84 times as long as prothorax, slightly thinner; dorsum rugosely punctured; punctures indistinct in apical 1/3. Antennal scape (Fig. 67) slender, 9.11 times as long as wide and 1.11 times as long as funicle, produced in a short lamina at apex; lamina with a long hair on dorsal surface; funicle (Fig. 66) with segment I 2.26 times as long as wide, as long as II, II slender, 3.64 times as long as wide, III 2.46 times as long as wide, 0.67 times as long as II, IV 2.20 times as long as wide, 0.90 times as long as III, 1.46 times as long as V, V 1.48 times as long as wide, 0.85 times as long as VI, VI 1.52 times as long as wide, 1.18 times as long as VII, VII 1.19 times as long as wide. 
Prothorax 1.25-1.29 times as wide as long, 0.42-0.45 times as long as and 0.59-0.64 times as wide as elytra, widest at base, subparallel-sided in basal $1 / 3$, then acutely and straightly convergent toward subapical constriction; dorsum finely and moderately punctured, with a deeper median sulcus, narrowly, strongly, and acutely prominent.

Elytra 1.09-1.14 times as long as wide, 2.21-2.38 times as long as and 1.57-1.71 times as wide as prothorax, with rather strong prominences.

Each femora armed with a larger tooth. Fore femora 4.69 times as long as wide, 1.27 times as long as and 2.17 times as wide as fore tibiae. Mid femora 4.07 times as long as wide, 1.36 times as long as and 2.14 times as wide as mid tibiae. Hind femora 3.81 times as long as wide, 1.30 times as long as and 2.29 times as wide as hind tibiae. Fore tibiae (Fig. 74) 8.00 times as long as wide; corbels longer, slightly dilated outward at apex. Mid tibiae (Fig. 75) 6.43 times as long as wide, each with a large mucro at apex. Hind tibiae (Fig. 76) 6.71 times as long as wide, with apices as in mid ones. Tarsi with segment V stouter.

Venter as in Figs. 83, 84; ventrite I widely and moderately concave on disc; ventrite II 0.48 times as long as I; ventrite $\mathrm{V}$ relatively wide, 4.18 times as wide as long, flat on disc.

Pygidium (Fig. 89) 1.50 times as wide as long, lustrous, strongly and rugosely punctured in addition to general minute punctation, devoid of concavity; each side of upper flange straight. Sternite IX as in Fig. 107. Tegmen (Fig. 108) with apodeme slenderer, nearly as long as tegminal ring. Aedeagal body (Figs. 105, 106) slenderer, subparallel-sided to apical 2/3, then rapidly narrowed apically, truncate at apex, moderately curved downward and slightly bent upward near apex in profile. Endophallus (Fig. 105) with pairs of comma-like sclerites and plate-like ones in basal part, lacking spicules. Otherwise practically as in H. nipponensis.

Femalle. Length of body: 2.08-2.18 mm (mean $2.12 \mathrm{~mm}$ ). Length of rostrum: 1.13-1.23 $\mathrm{mm}$ (1.18). Maximum width of pronotum: $0.80-0.88 \mathrm{~mm}(0.85)$. Length of pronotum: $0.63-$ $0.68 \mathrm{~mm}(0.65)$. Maximum width of elytra: $1.33-1.43 \mathrm{~mm}$ (1.39). Length of elytra: 1.48 $1.58 \mathrm{~mm}$ (1.52). $\mathrm{N}=5$, for all measurements.

Rostrum (Fig. 61) slightly longer, 1.78-1.88 times as long as prothorax. Antennae inserted just behind middle of rostrum (Fig. 61). Prothorax 1.26-1.36 times as wide as long. Elytra 1.07-1.13 times as long as wide. Tibiae simple at apex on all legs, not mucronate. Ventrites I and II slightly inflated, evenly and finely punctured. Ventrite V much narrower, 2.76 times as wide as long, with an elliptic concavity on disc. Pygidium (Fig. 90) smaller and wider, 3.61 times as wide as long, depressed, with a median carina extending from upper flange to lower margin, clothed only with fine hairs, devoid of scales. Ovipositor (Fig. 110) with coxites robust, nearly twice as long as styli; styli apicolaterally inserted, moderate in length, nearly twice as long as wide. Sternite VIII (Fig. 109) simple, lacking setae; arms markedly attenuate, nearly $1 / 3$ as long as apodemes, slightly longer than coxite and stylus combined, widely separated; apodemes moderate in length, moderately divergent near apex. Spermatheca (Fig. 111) with cornu robust, long, widely rounded at apex; collum broadly 
obliquely convex upward; ramus absent; insertions of duct and gland widely separated from each other. Otherwise practically as in male.

Type series. Holotype male (Type No. 3182, ELKU), near Mt. Ohtou, Wakayama, Honshu, Japan, 14. v. 1983, I. Matoba. Paratypes (EC, ELKU, HUM, HY, WPMNH). JAPAN: HONSHU. 2 males and 1 female, same data as the holoype. 1 female, same locality as the holotype, 3. v. 1979, I. Matoba. 1 male, Qhsugidani, Mt. Ohtou, Wakayama, 6. v. 1994, S. Nomura (from leaf-litter). 1 female, Reiganji, Hirogawa, Wakayama, 9. ii. 1990, I. Matoba (from leaf-litter) 1 male, Inami, Wakayama, 18. iv. 1989, S. Gotou. 1 male, Kuroe, Kainan, Wakayama, 11. vi. 1994, M. Murase. 1 female, Oku, Kibi, Wakayama, 8. iv. 1989, I. Matoba. 1 male and 1 female, Torinosu, Tanabe, Wakayama, 15. iv. 2001, S. Tanaka. SHIKOKU. 1 male, Ohasa, Naruto, Tokushima, 28. xii. 1999, H. Yokozeki. KYUSHU. 1 ex., Mt. Kurinodake, Kagoshima, 25. vii. 1974, T. Nakane. RYUKYUS. 1 female, Yodokogoya-Hananoego, Yakushima I., 26. x. 1979, H. Makihara. 1 ex., Kurio, Yakushima I., 12. v. 1985, T. Tanabe.

Distribution. Japan (Honshu, Shikoku, Kyushu, Ryukyus).

Etymology. The specific name refers to the dark body color with a blackish tinge.

\section{Key to Species of Ceutorhynchoides and Hainokisaruzo from Japan}

1 (4) Body (Figs. 1-4) robust, densely covered with broader scales. Rostrum (Figs. 11-16) shorter, less than 1.50 times (male) or 1.65 times (female) as long as prothorax. Antennal scape (Figs. 18, 20) rounded at apex and with 3-4 long hairs on ventral side. Antennal scrobes (Figs. 12, 13, 15, 16) clearly separated in entire width. Prothorax evidently raised on apical margin, lacking row of particular scales on basal margin. Elytral striae (Figs. 23, 26) with a median row of small scales. Tarsal claws (Figs. 33, 34) narrowly separated. Ventrite V (Fig. 36) wider, more than 4.50 times as wide as long. Male pygidium (Fig. 37) with a deep median furrow. Female ventrite V with an elliptic concavity in middle, bearing two scaly tufts at sides of it.

Ceutorhynchoides

2(3) Scales on prothorax and elytra (Figs. 21-23) longer and more erect. Antennal funicle (Fig. 17) slenderer, slightly longer than scape. Outer margin of fore tibia (Fig. 27) slightly expanded at apex. Tarsal segment V (Fig. 33) slenderer. Body length: 2.08$2.43 \mathrm{~mm}$. Ryukyus. C. squamatus

3(2) Scales on prothorax and elytra (Figs. 24-26) shorter and less erect. Antennal funicle (Fig. 19) stouter, slightly shorter than scape. Outer margin of fore tibia (Fig. 30) not expanded at apex. Tarsal segment V (Fig. 34) relatively robust. Body length: 2.00$2.43 \mathrm{~mm}$. Honshu, Shikoku, Kyushu. C. styracis

4(1) Body (Figs. 5-10) relatively slender, thinly covered with narrow scales. Rostrum (Figs. 53-61) longer, more than 1.55 times (male) or 1.70 times (female) as long as 
prothorax. Antennal scape (Figs. 63, 65, 67) bluntly projected and dorsally with hair or hair-like scale at apex. Antennal scrobes (Figs. 54, 55, 57, 58, 60, 61) fused basally on ventral surface of rostrum. Prothorax not or scarcely raised on apical margin, with 1-2 rows of dark narrow scales on basal margin. Elytral striae with a median row of minute hairs. Tarsal claws (Figs. 77, 78) widely separated. Ventrite V (Figs. 80, 82, 84) narrower, less than 4.50 times as wide as long. Male pygidium and female ventrite $\mathrm{V}$ devoid of evident concavity. Hainokisaruzo

5 (6) Brown in general appearance; rostrum, antennae, and legs tinged with yellow (Figs. 56). Prothorax relatively long and wide, nearly 0.50 times as long as and 0.70 times as wide as elytra; dorsum coarsely, shallowly, and reticulately punctured, widely prominent in middle. Elytral sides straightly and rather abruptly convergent from middle toward subapical calli; intervals evenly with minute granules. Hind femora robust, nearly 3.20 times as long as wide. Tarsal claws sharply appendiculate (Fig. 77). Body smaller, 1.75-2.03 mm in length. Honshu, Kyushu. H. japonicus

6 (5) Dark brown in general appearance (Figs. 7-10). Prothorax relatively short and narrow, less than 0.45 times as long as and 0.65 times as wide as elytra; dorsum closely or moderately punctured, narrowly prominent in middle. Elytral sides moderately convergent from middle toward subapical calli; intervals bearing granules only on tubercles. Hind femora slender, nearly 4.00 times as long as wide. Tarsal claws obtusely appendiculate (Fig. 78). Body larger, 1.90-2.18 $\mathrm{mm}$ in length.

7 (8) Forehead (Fig. 53) narrower than basal width of rostrum. Rostrum (Figs. 53-55) slightly stouter, 1.74-1.77 times (male) or 1.75-1.83 times (female) as long as prothorax, moderately punctured. Antennal scape (Fig. 63) robust, apically with slender scale at apex. Prothorax plump, 1.36-1.44 times as wide as long; dorsum coarsely punctured, with a shallow sulcus and blunt tubercles in middle. Elytral prominences rather weak. Male pygidium (Fig. 85) widely concave in middle. Female pygidium (Fig. 86) larger, transverse-pentagonal. Body length: 1.90-2.10 mm. Honshu.

H. nipponensis

8 (7) Forehead slightly wider than basal width of rostrum. Rostrum (Figs. 59-61) slenderer, 1.73-1.84 times (male) or 1.78-1.88 times (female) as long as prothorax, rugosely punctured. Antennal scape (Fig. 67) slender, bearing a long hair at apex. Prothorax narrower, 1.26-1.36 times as wide as long; dorsum finely punctured, with a deep sulcus and acute tubercles in middle. Elytral prominences rather strong. Male pygidium (Fig. 89) devoid of median concavity. Female pygidium (Fig. 90) smaller, eyeshaped. Body length: 2.03-2.18 mm. Honshu, Shikoku, Kyushu, Ryukyus.

H. infuscatus 


\section{Acknowledgments}

We thank Prof. O. Tadauchi (ELKU) for his review of an early draft. Our thanks are also due to the following persons for the loan of specimens and/or the offer of biological information: Mr. Y. Hirano (Odawara), Mr. M. Horikawa (Yokohama), Mr. H. Ichihashi (Komono), Mr. K. Izawa (Tajimi), Mr. K. Kannou (Komono), Dr. H. Kojima (Fukuoka), Mr. I. Matoba (WPMNH), Mr. T. Nohira (Kagamihara), Dr. Y. Okushima (Kurashiki), Dr. N. Ohbayashi (ELEU), Dr. M. Ôhara (HUM), Dr. H. Perrin (MNHN), Dr. M. Sakai (ELEU), Dr. N. Takahashi (Fukuoka), Mr. T. Tenma (Owase), and Mr. A. Yoshida (Inagi). We acknowledge Prof. Emeritus K. Morimoto (ELKU) for his help in the course of this stuby. This study was supported in part by a grant from the JSPS Research Fellowships for Young Scientists (No. 14009292).

\section{References}

Colonnelli, E., 1979. Ergebnisse der Bhutan-Expedition 1972 des Naturhistorischen Museums in Basel. Coleoptera: Curculionidae: Subf. Ceutorhynchinae. Ent. basil., 4: 141-156.

Colonnelli, E., 1984. Trois espèces et deux genres nouveaux de Ceutorhynchinae de l'Inde (Coleoptera, Curculionidae). Annls. hist.-nat. Mus. natn. hung., 76: 201-205.

Colonnelli, E., 2004. Catalogue of Ceutorhynchinae of the World, with a Key to Genera (Insecta: Coeloptera: Curculionidae). Argania editio, Barcelona.

Dalla Torre, K. W. von \& A. Hustache, 1930. Coleopterorum Catalogus auspiciis et auxilio W. Junk editus a S. Schenkling. Pars 113. Curculionidae: Ceuthorrhynchinae. Junk, Berlin.

Egorov, A. B., V. V. Zherikhin \& B. A. Korotyaev, 1996. Curculionidae. In Ler, P. A. (ed.), Key to the Insects of Russian Far East, 3 (3): 249-311, 431-516. Dal'nauka, Vladivostok. (In Russian.)

Hustache, A., 1916. Synopsis des Ceuthorrhynchini du Japon. Annls. Soc. ent. Fr., 85: 107144.

Korotyaev, B. A., 1981. New and little known weevils of the subfam. Ceutorhynchinae (Coleoptera, Curculionidae) from the Palaearctic, Indomalayan and Australian regions. Ent. Obozr., 60: 126-158. (In Russian.)

Korotyaev, B. A., 1989. New species of the weevil subfamily Ceutorhynchinae (Coleoptera, Curculionidae) from the Indo-Malayan region. Proc. zool. Inst., Leningrad, 208: 125156. (In Russian.)

Korotyaev, B. A. \& K.-J. Hong, 2004. A revised list of the weevil subfamily Ceutorhynchinae (Coleoptera: Curculionidae) of the Korean Fauna, with contribution to the knowledge of the fauna of neighbouring countries. J. Asia-Pacific Entomol., 7 (2): 143-169. 
Morimoto, K., 1962. Provisional check list of the family Curculionidae of Japan. I. Sci. Bull. Fac. Agric. Kyushu Univ., 19: 183-217.

Morimoto, K., 1984. Curculionidae. In: Hayashi, M., K. Morimoto \& S. Kimoto (eds.), The Coleoptera of Japan in Color, 4: 269-345. Hoikusha, Osaka. (In Japanese.)

Morimoto, K., 1989. Curculionoidea. In: Hirashima, Y. (superv.), A Check List of Japanese Insects: 485-538. Entomological Laboratory, Kyushu University, Fukuoka.

Satake, Y., H. Hara, S. Watari \& T. Tominari, 1989a. Wild Flowers of Japan. Woody Plants I. Heibonsha, Tokyo. (In Japanese.)

Satake, Y., H. Hara, S. Watari \& T. Tominari, 1989b. Wild Flowers of Japan. Woody Plants II. Heibonsha, Tokyo. (In Japanese.)

Yoshitake, H. \& T. Yamauchi, 2002. A new genus of the Oriental tribe Mecysmoderini (Coleoptera, Curculionidae, Ceutorhynchinae), with descriptions of two new species from Indonesia and Malaysia. Spec. Bull. Jpn. Soc. Coleopterol., Tokyo, (5): 413-423.

Yoshitake, H., H. Kojima \& K. Morimoto, 2004. Ceutorhynchinae. In: Kojima, H. \& K. Morimoto, An online checklist and database of the Japanese weevils (Insecta; Coleoptera; Curculionoidea) (excepting Scolytidae and Platypodidae), Bull. Kyushu Univ. Mus., (2) : 100-106. 
